\title{
LE CULTE MÉDIÉVAL DE SAINT VENCESLAS ET DE SAINT ADALBERT EN EUROPE CENTRALE
}

\author{
Petr Kubín \\ Univerzita Karlova v Praze
}

\begin{abstract}
THE CULT OF ST. WENCESLAS AND ST. ADALBERT IN MEDIEVAL CENTRAL EUROPE
\end{abstract}

The cult of the two main Bohemian patron saints, Wenceslas († 935) and Adalbert ( $†$ 997), played an important role in the Middle Ages not only in the Czech state but also in Poland and Hungary. Apart from this, it also penetrated different parts of the medieval Roman Empire. Wenceslas was proclaimed saint only after the foundation of Prague Bishopric (973), and Adalbert was canonized directly after his martyrdom at Bolesław the Brave's order. Unlike the cult of Wenceslas, Adalbert's cult developed dynamically from the very beginning and with extraordinary aspirations, since emperor Otto III intended Adalbert to become one of the imperial saints. Unfortunately, this plan failed due to the early death of Otto III. Nevertheless, Adalbert's cult was adopted in Poland and Hungary, where the local church structures were consequently built on its basis in the year 1000 , while St. Wenceslas became the main patron saint of Bohemia.

Key words: Middle Ages, St. Wenceslas, St. Adalbert, Central Europe, cult, saints.

Słowa kluczowe: średniowiecze, św. Wacław, św. Wojciech, Europa Środkowa, kult, święci.

Mots-clés: Moyen-âge, saint Venceslas, saint Adalbert, Europe centrale, culte, saints.

Le culte des deux principaux saints patrons tchèques, Venceslas et Adalbert, a joué un rôle important au Moyen-âge, non seulement au sein de l'Etat tchèque, mais également en Pologne et en Hongrie. Il s'est en outre diffusé également dans différentes parties de l'Empire romain médiéval. Le sujet de cette étude vise à saisir de manière générale la genèse et le développement de leur culte, dans les royaumes de l'Europe centrale, mais aussi dans l'empire, à partir de l'état actuel des connaissances des sciences historiques. 


\section{SAINT VENCESLAS}

Le duc de Bohême Venceslas a été assassiné avec préméditation par son frère Boleslav I ${ }^{\mathrm{er}}$, dans son château de Stará Boleslav, le lundi 28 septembre $935^{1}$. Boleslav reprochait essentiellement à Venceslas de s'être placé sous la férule de l'empire. C'est pourquoi, immédiatement après avoir pris le pouvoir, il déclara la guerre au roi germanique Otton I ${ }^{\text {er }}$, conflit qui perdura jusqu'en 950 lorsque Boleslav dut finalement admettre sa défaite ${ }^{2}$. La reconnaissance de la tutelle d'Otton ${ }^{\text {er }}$ conduisit à la réhabilitation de la politique de Venceslas. Le signe extérieur de ce retournement furent les nouvelles funérailles de Venceslas dans la traditionnelle nécropole přemyslide au Château de Prague. Pour accueillir le tombeau de Venceslas, on rajouta à l'imposante rotonde castrale Saint-Guy, une abside méridionale, à l'endroit le plus en vue du Château'.

D'après les légendes, Venceslas aurait lui-même choisi cette rotonde comme lieu de son dernier repos. En tout état de cause, son culte à venir fut à jamais lié justement à cette église. Sa construction avait pris fin en 929 ou 930 , à l'époque où le roi germanique Henri l'Oiseleur avait conquis Prague et accepté le serment de fidélité de Venceslas, ainsi que son engagement à lui payer le tributum pacis. Le roi scella alors cet accord de paix par le don de la dépouille de saint Guy, vénéré par les Saxons, et auquel Venceslas dédia promptement la nouvelle rotonde 4 .

Mais l'acte de transport de la dépouille de Venceslas de Stará Boleslav à Prague, décrit avec force détails et de manière dramatique par les légendes, peut difficilement être considéré comme une canonisation sous forme de translation (comme l'ont cru

1 Il existe une somme extrêmement importante d'ouvrages sur saint Venceslas et son culte. Je me limiterai donc à la littérature récente : D. Třeštík, Počátky Přemyslovců. Vstup Čechů do dějin /530-935/, Praha 1997; J. Nastalska-Wiśnicka, Rex martyr. Studium źródtoznawcze nad legendą hagiograficzna św. Wactawa (X-XIV w.), Lublin 2010; Svatý Václav, ed. P. Kubín, Praha 2010 ; P. Kubín, Sedm přemyslovských kultů, Praha 2011, p. 125-150; V. Vaníček, Svatý Václav. Panovník a světec v raném středověku, Praha-Litomyšl 2014; J. Sláma, Kniže sv. Václav [in:] J. Sláma et al., Středni Čechy, kolébka národních patronů, sv. Ludmila, sv. Václav, sv. Vojtěch, sv. Prokop, Kladno 2015, p. 89-114.

2 Widukindi monachi Corbeiensis Rerum gestarum Saxonicarum libri tres, ed. P. Hirsch, H.-E. Lohmann, Monumenta Germaniae Historica, Scriptores Rerum Germanicarum in usum scholarum [ci-dessous MGH SRG] 60, Hannover 1935, II/3, p. 68-70 et III/8, p. 108-109.

3 La rotonde se trouvait en effet sur un éperon rocheux, visible de loin depuis la Vltava. Cf. J. Maříková-Kubková, I. Herichová, Archeologický atlas Pražského hradu 1 - Katedrála sv. VítaVikářská ulice (= Castrum Pragense 10), Praha 2009.

4 Widukind I/35, p. 50 („Post haec Pragam /Henricus rex/ adiit cum omni exercitu, Bohemiorum urbem, /Wenceslaum/ regemque eius in deditionem accepit...”). Pour la date de la consécration du 22 septembre 929 (930) cf. D. Třeštík, op. cit., p. 89, partic. note 125. Le don des reliques est mentionné pour la première fois par la légende de saint Venceslas Ut annuncietur I (Bibliotheca hagiographica latina antiquae et mediae aetatis, Bruxelles 1898-1901 [ci-dessous: BHL] 8832), rédigée par un chanoine pragois inconnu au cours des années 1230-1250. Cf. Vita sancti Wenceslai incipiens verbis ,,Ut annuncietur", ed. A. Podlaha, Praha 1917, p. 25-27. Néanmoins, supposer qu'Henri l'Oiseleur déjà ait fait don de ces reliques est tout-à-fait logique. 
et le croient encore certaines historiens) $)^{5}$, car à côté du tombeau de l'église SaintGuy ne fut pas élevé un autel dédié à saint Venceslas mais aux Douzes apôtres. Et pourtant, on commença bientôt à se souvenir de Venceslas comme d'un bon prince chrétien, ce que dès les années 950 reproduisit la première légende latine, malheureusement disparue (nommée $\mathrm{X})^{6}$, et peu de temps après (sans doute dans les années 960), sa version écourtée en ancien slavon, connue sous le titre La première légende slavone ${ }^{7}$. Dans cette légende slavone, Venceslas n'est pas encore présenté comme un saint ; au contraire, on y récite une prière pour son salut. Cependant, y apparaît un premier miracle - trois jours durant, il aurait été impossible de nettoyer le sang du mur auprès duquel il fut assassiné. On commence alors à parler de lui en lien avec des signes miraculeux dont les échos sont elevés en premier (sans plus de détails) par le moine saxon Widukind, dans sa chronique des années 967/968. La constitution d'un culte publique à saint Venceslas se produisit probablement après la création de l'évêché de Prague (973) et la consécration du premier évêque de Prague Dietmar (janvier 976), dont les compétences comprenaient notamment la canonisation. A cette époque, le fratricide Boleslav ${ }^{\text {er }}$ était déjà mort depuis plusieurs années, et en Bohême régnait son fils Boleslav II (972-999) qui n'était pas entaché de la mort du saint. La désignation de Venceslas en tant que saint est confirmée par la nouvelle légende latine Crescente fide (BHL 8823), rédigée d'après une commande pragoise à l'abbaye Saint-Emmeran de Ratisbonne, entre 976 et 983 . Son auteur y décrit incontestablement Venceslas comme un saint auquel seraient liés de nombreux miracles après sa mort ${ }^{8}$.

Le culte de saint Venceslas a largement bénéficié du fait que le second évêque de Prague ait été saint Adalbert, qui réussit à le diffuser de manière efficace, même au-delà des frontières du royaume de Bohême. Dès juin 983 , il fit le nécessaire auprès de l'empereur Otton II pour que Gumpold, l'évêque de Mantoue, améliore les qualités littéraires de la simple légende Crescente fide. L'objectif fut atteint : la nouvelle légende de Gumpold (BHL 8821) devint rapidement la plus populaire des légendes consacrées à saint Venceslas, et fut même traduite en ancien slavon (= La deuxième

5 Par ex. J. Cibulka, Václavova rotunda svatého Vita [in:] Svatováclavský sborník I - Kníže Václav Svatý a jeho doba, ed. K. Stloukal, J. Kapras, K. Guth, A. Novák, Praha 1934, p. 230-685, ici p. 366-377; R. Turek, Svatý Václav [in:] Bohemia sancta. Životopisy českých světcủ a prátel božích, ed. J. Kadlec, Praha 1989, p. 53-71, ici p. 64; J. Nastalska-Wiśnicka, op. cit., p. 236-237.

6 Son existence, longtemps contestée, a été prouvée par D. Třeštík, op. cit., p. 225-248.

7 Les éditions des trois versions conservées de la Première légende slavone se trouvent dans Sbornik staroslovanských literárních památek o sv. Václavu a sv. Ludmile, ed. J. Vajs, Praha 1929, p. 11-43. À propos de l'hagiographie de Venceslas, cf. J. Nastalska-Wiśnicka, op. cit.; P. Kubín, op. cit., p. 125-150. Particulièrement, sur Christian et la Première légende slavone D. Kalhous, Anatomy of a Duchy. The Political and Ecclesiastical Structures of Early Přemyslid Bohemia, Leiden-Boston 2012, p. 171-262; D. Kalhous, Legenda Christiani and Modern Historiography, Leiden-Boston 2015.

8 Crescente fide nous est parvenu sous deux versions - l'une bavaroise, l'autre tchèque. La plus ancienne, bavaroise, a été éditée par J. Emler, Život sv. Václava [in:] Fontes rerum Bohemicarum (ci-dessous FRB) 1, Praha 1873, p. 183-190, la plus tardive, tchèque, par J. Ludvíkovský, Nově zjištěný rukopis legendy Crescente fide a jeho význam pro datováni Kristiána, „Listy filologické” 1958, 6, p. 56-68, partic. p. 58-63. 
légende slavone) $)^{9}$. A cette époque, la fête liturgique de Venceslas était déjà célébrée même dans le diocèse de Ratisbonne, comme le prouve le sacramentaire de l'évêque local Wolfgang, datant des années $992-994^{10}$. On commença à placer des reliques de Venceslas dans les autels de grandes églises de l'empire, la première mention prouvée remontant à 992, date à laquelle fut consacrée la nouvelle cathédrale d'Halberstadt $^{11}$, puis lors de la consécration de la cathédrale de Bamberg $(1012)^{12}$, puis de celle de la chapelle palatinale Saint-Servais à Quedlinburg $(1021)^{13}$.

La première église à être (co-)consacrée à Venceslas fut la cathédrale de Prague. Dans le prétendu acte de fondation de l'évêché de Prague, dont le texte est mentionné dans la chronique de Cosmas, le pape Jean XIII aurait placé la cathédrale de Prague sous la protection de saint Guy et saint Venceslas ${ }^{14}$. Il semblerait que l'extension du patrocinium se soit produite juste après la canonisation de Venceslas par l'évêque de Prague Dietmar.

Peu de temps après, une deuxième église fut consacrée à Venceslas, cette foisci loin de Prague, dans le principal château des Vislanes à Cracovie. Certes, les sources écrites ne mentionnent le patrocinium de Venceslas au Wawel qu'à partir de $1110^{15}$, mais il est pratiquement certain qu'il soit plus plus ancien ${ }^{16}$. Le prince de Bohême Boleslav Ir avait conquis la région de Cracovie, ainsi que la Moravie du nord et la Silésie aux alentours de 940 et depuis lors, une garnison tchèque se trouvait sur le Wawel ${ }^{17}$. C'est justement elle qui fit vraisemblablement construire

9 Druhá staroslovanská legenda o sv. Václavu, ed. J. Vašica [in:] Sborník staroslovanských památek o sv. Václavu a sv. Lidmile, ed. J. Vajs, Praha 1929, p. 71-135.

10 Biblioteca Capitolare Verona, Cod. LXXXVII. Cf. F. Stejskal, Svatý Václav. Jeho život a úcta, Praha 1925, p. 143; R. Kahsnitz, Sakramentar des hl. Wolfgang [in:] Otto der Grosse. Magdeburg und Europa. Ausstellungskatalog, ed. M. Puhle, Mainz 2001, p. 275-278.

11, ,...] vesta sanguinea sancti Wenezlai martiris [...]” Annalista Saxo, ed. K. Nass, Monumenta Germaniae Historica, Scriptores [ci-dessous MGH SS] 37, Hannover 2006, p. 254.

12 Annales et notae Babenbergenses, MGH SS 17, ed. Ph. Jaffé, Hannover 1861, p. 634-642, ici p. 636 et 638 .

13 Annales Quedliburgenses, MGH SS 3, ed. G.H. Pertz, Hannover 1839, p. 72-90, ici p. 87.

14 Cosmae Pragensis Chronica Boemorum, Monumenta Germaniae Historica, Scriptores Rerum Germanicarum, Nova Series, [ci-dessous MGH SRG n. s.] 2, ed. B. Bretholz, Berlin 1923, I/22, p. 4344.

15 „Invente sunt autem in erario sancti Vencezlai”. Spisy dawne skarbca i biblioteki kapitulnej krakowskiej [in:] Monumenta Poloniae Historica [ci-dessous MPH] 1, ed. A. Bielowski, Lwów 1864, p. 376-378, ici p. 377.

16 Les anciens textes (T. Wojciechow ski, Kościót katedralny w Krakowie, Kraków 1900, p. 54 61; W. Schenk, Kult świętych w Polsce, „Roczniki Teologiczno-Kanoniczne” 1966, 13, p. 77-102, ici p. 88) estimait que le patron d'origine de la cathédrale était saint Sauveur. Mais la justification était assez faible - prétendûment parce que la consécration de la cathédrale du 20 avril (sic !) s'était déroulée le Dimanche des Rameaux, qui est aussi la fête du Sauveur, que ce dernier est représenté sur les clefs de voûte gothiques du presbytère de la cathédrale aux côtés de Venceslas et Stanislas, et qu'enfin le Christ sur la croix avait toujours été représenté sur l'autel principal.

17 Cracovie est mentionnée pour la première fois dans les sources écrites dans un message du commerçant juif Ibrahim ibn Jakub des années 965/966. Il en parle comme faisant partie de l'Etat přemyslide. Aux alentours de 960, Boleslav I ${ }^{\text {er }}$ s'empara de la Slovaquie, de la région de Sandomierz et de la Ruthénie rouge, son empire finissant ainsi aux frontières de la Rus' de Kiev. Des milliers de 
l'église Saint-Venceslas ${ }^{18}$, mais ceci dut se produire après la canonisation officielle de Venceslas à Prague, soit après 976. Peu de temps après, au plus tard en 984, la région de Cracovie tomba entre les mains Mieszko ${ }^{\text {er }}$, duc des Polanes, qui confia la gestion du territoire conquis à son fils Boleslas $1^{\text {er }}$ Vaillant. Sa mère était une Př́emyslide, Doubravka. Il n'est donc guère étonnant que Boleslas ler Vaillant (souverain de toute la Pologne à partir de 992) ait continué à soutenir le culte de saint Venceslas. Il avait probablement l'intention dès le début de faire de saint Venceslas le patron de la dynastie Piast ${ }^{19}$, car au revers des deniers qui lui sont dédiés se trouve l'inscription VENCIEZLAVVS ${ }^{20}$. D'après certains chercheurs, l'église Saint-Venceslas sur le Wawel ne fut établie que sous son règne ${ }^{21}$. On ne peut pas non plus exclure cette possibilité. En tout état de cause, c'est justement cette église - même s'il y en avait plusieurs autres à l'époque sur le Wawel - qui fut choisie en l'an 1000 pour être la cathédrale du tout nouveau diocèse de Cracovie. Ce n'est pas tant le patrocinium qui influença le choix, mais plutôt le fait qu'elle était la plus grande de toutes ${ }^{22}$.

kilomètres de routes commerciales menant de Ratisbonne, passant par Prague et Cracovie et allant jusqu'à Kiev, se retrouvèrent ainsi sous le contrôle des Přemyslides. Une garnison tchèque fut placée dans les châteaux des tribus slaves assujetties, dont le château principal des Vislanes à Cracovie. Outre la présence militaire, les Tchèques limitaient leur action sur ce territoire conquis à la collecte d'un tribut, la dépendance au pouvoir přemyslide étant sinon plutôt relâchée. Boleslav ${ }^{\mathrm{er}}$ entretenait en même temps une relation amicale avec le duc des Polanes, Mieszko I ${ }^{\text {er }}$ L'illustration de cette coopération fut son mariage avec la fille de Boleslav, Dąbrówka en 965. Cette alliance n'eut pas qu'une importance politique mais aussi religieuse, car l'année suivante, Mieszko se convertit au christianisme sous l'influence de son épouse. Boleslav Ir envoya ensuite sa seconde fille Mlada à Rome pour demander l'autorisation au pape de créer un évêché à Prague et Poznań, ce qui fut d'ailleurs fait. Tandis qu'à Poznań, l'évêché fut créé presque immédiatement (968, évêque Jordan), à Prague, il fallut attendre jusqu'en 973, date à laquelle le nouvel évêque de Ratisbonne, Wolfgang, donna son feu vert. Mais cette coopération presque idyllique entre les Tchèques et les Polonais ne dura pas longtemps. A ce propos, cf. M. Lutovský, Bratrovrah a tvuirce státu. Život a doba knižete Boleslava I., Praha 2006, p. 139-144; M. Matla-Kozłowska, Pierwsi Przemyślidzi i ich państwo (od X do połowy XI wieku). Ekspansja terytorialna i jej polityczne uwarunkowania, Poznań 2008, p. 219-239; K. Ożóg, 966. Chrzest Polski, Kraków 2016, p. 82-115.

18 Ainsi B. Kürbis, O życiu religijnym w Polsce X-XII wieku [in:] Pogranicza i konteksty literatury polskiego średniowiecza, ed. T. Michałowska, Wrocław 1989, p. 7-55, ici p. 31. En outre, selon P. David (Les bénédictins et l'ordre de Cluny dans la Pologne médiévale, Paris 1939, p. 24) l'église Saint-Venceslas existait déjà en lieu et place de l'actuelle cathédrale, avant la création de l'évêché.

19 Ainsi Z. Kozłowska-Budkowa, Który Bolesław? [in:] Prace z dziejów Polski feudalnej ofiarowane Romanowi Grodeckiemu, ed. Z. Kozłowska-Budkowa et al., Warszawa 1960, p. 81-89; T. Dunin-Wąsowicz, Kulty świętych w Polsce w X wieku [in:] Polska w świecie. Szkice z dziejów kultury polskiej, Warszawa 1972, p. 72-73; A. Witkowska, Titulus ecclesiae - Historia. Wezwania wspótczesnych kościołów katedralnych w Polsce, Warszawa 1999, p. 234.

20 S. Suchodolski, Kult svatého Václava a svatého Vojtěcha prizmatem raně středověkých polských mincí, „Numismatický sborník” 2005, 20, p. 29-42; B. Paszkiewicz, Svatý biskup na polských středověkých mincích [in:] Po stopách sv. Vojtěcha (= Antiqua Cuthna 3), ed. J.K. Kroupa, L. Polanský, J. Sláma, V. Vaněk, Praha 2014, p. 141-159, ici p. 142.

21 Ainsi Z. Kozłowska-Budkowa, op. cit., p. 88-89; G. Labuda, Mieszko II, król Polski (10251034). Czasy przełomu w dziejach państwa, Kraków 1992, p. 43; A. Witkowska, op. cit., p. 234.

22 L'église castrale d'origine, consacrée à saint Venceslas et située sur le Wawel, se trouvait vraisemblablement à l'endroit de l'actuelle cathédrale gothique datant de l'époque de Casimir le Grand. Sous son sol, les archéologues ont retrouvé deux constructions sacrales plus anciennes. La première se 
Cent quarante ans plus tard, Venceslas devint le saint patron d'une troisière cathédrale, à nouveau à l'est de Prague. Cette fois-ci, à Olomouc, qui était l'un des trois sièges des duchés donnés en apanage de la dynastie des Přemyslides en Moravie. C'est le duc local Svatopluk qui entama la construction de l'église Saint-Venceslas dans l'enceinte du château des Přemyslides dans les années 1104-1107. Elle fut consacrée en 1131 par l'évêque d'Olomouc Henri Zdík. Dix ans plus tard, dans le cadre des réformes administratives de son diocèse, Zdík y fit transférer la cathèdre épiscopale depuis l'église plus ancienne consacrée à saint Pierre ${ }^{23}$.

Outre trois cathédrales, d'autres églises furent par la suite consacrée à Venceslas. Tout d'abord, sur le site même de son martyre, au château de Stará Boleslav, où le duc de Bohême Břetislav I ${ }^{\text {er }}$ fonda en 1046, en son honneur, une chapitre collégial, le premier du genre en pays tchèques ${ }^{24}$. D'autres églises Saint-Venceslas virent le jour en Bohême et en Moravie, tant dans des monastères (par exemple, les prémontrés à Louka près Znojmo, en 1190, ou les prémontrées à Chotěšov aux alentours de $1201)^{25}$, que dans des villages et des villes ${ }^{26}$. En Bohême, ce sont pas moins de vingtcinq églises romanes consacrées à saint Venceslas qui furent ainsi édifiées ${ }^{27}$.

La diffusion du culte ne pouvait se faire sans les indispensables textes hagiographiques qui se lisaient dans les monastères dans le cadre des prières chorales et dans les réfectoires lors des repas en commun. La plupart vit le jour en pays tchèques, certains hors de leurs frontières sur commande tchèque (par exemple La légende de Laurent/BHL 8824/ au Monte Cassino autour de 1039) ${ }^{28}$. Le plus célèbre d'entre eux est désigné d'après le nom de son auteur supposé, La légende de Christian, (BHL

trouve dans la partie septentrionale de l'actuelle cathédrale : il s'agit de restes d'une rotonde à une seule abside, dont la nef faisait environ $7 \mathrm{~m}$. Au centre de la nef, on a retrouvé une excavation isocèle maçonnée qui devait servir de piscine baptismale. Les restes de maçonnerie de la deuxième construction se trouvent sous la partie orientale. Il s'agit d'une basilique romane, probablement de l'époque de Boleslas le Vaillant, qui, dans la première moitié du XII ${ }^{\mathrm{e}}$ siècle, fut remplacée par une basilique à deux chœurs de plus grande envergure. C'est le duc Vladislas ${ }^{\text {er }}$ Herman qui lança sa construction, mais elle ne fut consacrée qu'en 1143, soit peu de temps après la mort de Boleslas III Bouche-Torse. A propos de l'archéologie des plus anciennes constructions sacrales sur le Wawel, cf. Z. Pianowski, Krakau (Kraków) [in:] Europas Mitte um 1000. Beiträge zur Geschichte, Kunst und Archäologie, ed. A. Wieczorek, H.-M. Hinz, Stuttgart 2000, p. 479-482; Z. Kurnatowska, Die Christianisierung Polens im Lichte der archäologischen Quellen [in:] Europas Mitte um 1000..., p. 490-493; Z. Pianowski, Architektura monumentalna wczesnośredniowiecznego Krakowa [in:] Kraków w chrześcijańskiej Europie X-XIII w., ed. E. Firlet, E. Zaitz, Kraków 2006, p. 163-219, ici p. 167-185.

${ }^{23}$ A ce propos cf. M. Wihoda, Morava v době knížeci 906-1197, Praha 2010, p. 183-186.

24 Cosmae Pragensis Chronica II/7, p. 93.

${ }_{25}$ Z. Boháč, Patrocinia kostelì při nejstaršich klášterech a kapitulách v českých zemích, „Historická geografie" 1970, 5, p. 51-76.

26 Z. Boháč, K otázce zasvěceni kostelů v oboru historické geografie, „Československý časopis historický" 1968, 16, p. 571-584.

27 Z. Boháč, Patrocinia románských kosteli̊ v Čechách, „Historická geografie” 1972, 8, p. 31-52, ici p. 43.

28 Laurentius, monachus Casinensis, archiepiscopus Amalfitanus, Opera, MGH, Quellen zur Geistesgeschichte des Mittelalters 7, ed. F. Newton, Weimar 1973. A ce propos, cf. D. Třeštík, Miscellanea zu den St. Wenzelslegenden 2: Laurentius aus Monte Cassino und Laurentius aus Amalfi, „Mediaevalia Bohemica” 1969, 1, p. 73-92. 
8825), dont l'ancienneté fait débat chez les historiens depuis plus de 200 ans, la datation oscillant entre le $\mathrm{X}^{\mathrm{e}}$ et le $\mathrm{XIV}^{\mathrm{e}}$ siècle ${ }^{29}$. D'après moi, elle a été probablement écrite au chapitre épiscopal de Prague avant la moitié du XII ${ }^{e}$ siècle ${ }^{30}$. Cette légende a eu une influence majeure sur l'hagiographie de Venceslas aux XIII ${ }^{e}$ et XIV siècles, où furent écrites les nouvelles et longues légendes (sous plusieurs versions), Ut annuncietur (BHL 8832) (1) $^{31}$ et Oriente iam sole (BHL 8827) ${ }^{32}$.

En Bohême, dès les XI et XII ${ }^{e}$ siècles, le culte de saint Venceslas s'est progressivement transformé en symbole institutionnel, où le saint duc remplaçait en fait la notion abstraite d'Etat. D'après les représentations politico-religieuses de l'époque, saint Venceslas régnerait sur la Bohême pour l'éternité et il ne confiait la gestion de son pays uniquement de manière temporaire aux différents ducs et plus tard, aux rois ${ }^{33}$. Ce mythe fut incarné tout d'abord sur les deniers tchèques sur lesquels était gravé le nom de Venceslas depuis l'époque du duc Jaromír (1003, 1004-1012 et 1033-1034) et, avec la monnaie frappée par le neveu de Jaromír, Břetislav I ${ }^{\text {er }}(1034-1055)$, on y trouva même le portrait de Venceslas bénissant, son étendard à la main ${ }^{34}$. Un siècle plus tard, en lien avec la création d'une chancellerie royale permanente, Venceslas commença à apparaître de la même façon au dos du sceau royal, tandis que sur le recto était en général représenté l'auteur du document. Y était adjointe l'inscription éloquente pax sancti Wenceslai in manu ducis/regis $X Y$, signifiant que le bon règne de saint Venceslas était désormais entre les mains de tel ou tel souverain ${ }^{35}$. Venceslas aidait également le peuple tchèque sur les champs de bataille ${ }^{36}$. Il aurait été ainsi aper-

${ }^{29}$ Kristiánova legenda / Legenda Christiani, ed. J. Ludvíkovský, Praha 1978. A ce propos cf. E. Glushko, Medieval Challenges Modern. Legenda Christiani and Its Author in Czech Historiography, Saarbrücken 2008; D. Kalhou s, Legenda Christiani and Modern Historiography, Leiden-Boston 2015.

30 P. Kubín, op. cit., p. 89-118.

31 Vita sancti Wenceslai incipiens verbis „Ut annuncietur”, ed. A. Podlaha, Praha 1917. A ce propos J. Ludvík ov ský, Václavská legenda XIII. století „Ut annuncietur”, její poměr k legendě Oriente a otázka autorství, „Listy filologické” 1955, 3, p. 196-205.

32 Die Wenzelslegende „Oriente iam sole“/Die erste Rezension/, ed. J. Pekař, Die Wenzels- und Ludmila- Legenden und die Echtheit Christians, Praha 1906, p. 409-430. A ce propos, cf. la bibliographie dans P. Kubín, op. cit., p. 127-128.

33 A propos du thème du souverain éternel, cf. F. Graus, Kirchliche und heidnische (magische) Komponenten der Stellung der Přemysliden. Přemyslidensage und St. Wenzelsideologie [in:] Siedlung und Verfassung Böhmens in der Frühzeit, red. F. Graus, H. Ludat, Wiesbaden 1967, p. 148-161, ici p. 158-161; F. Graus, Böhmen zwischen Bayern und Sachsen, „Historica” 1969, 17, p. 5-42, ici p. 35; A. Merhautová, D. Třeštík, Ideové proudy v českém umění 12. století, Praha 1985, p. 82-105; D. Třeštík, Idea státu a národa [in:] Přemyslovci. Budování českého státu, ed. P. Sommer, D. Třeštík, J. Žemlička, Praha 2009, p. 272-286, ici p. 281-282; J. Žemlička, Svatý Václav jako věčný kniže „Čechĩ “ [in:] Svatý Václav, ed. P. Ku bín, p. 211-220.

34 P. Radoměrský, V. Ryneš, Společná úcta sv. Václava a sv. Vojtěcha zvláště na českých mincích a její historický význam, „Numismatické listy” 1958, 13, p. 35-48; V. Ryneš, J. Hásková, K počátkům svatováclavského motivu na českých denárech, „Numismatické listy” 1967, 22, p. 145-152.

35 A commencer par les sceaux les plus anciens de Vladislav II des années 1142-1148 portant l'inscription „Pax sancti Wazezlai in manu ducis Vadizlaus”. Cf. J. Čarek, O pečetěch českých knižat a králi z rodu Přemyslova, Sborník př́spěvků k dějinám hl. m. Prahy 8, 1938, p. 1-56.

36 F. Graus, Die Heilige als Schlachtenhelfer. Zur Nationalisierung einer Wundererzählung in der mittelalterlichen Chronistik [in:] Festschrift für Helmut Beumann, ed. K.-U. Jäschke, R. Wenskus, 
çu lors de la célèbre bataille de Chlumec, au pied des Monts métallifères, en février 1126 , où le duc de Bohême Soběslav Ir $^{\text {er }}$ sortit vainqueur contre le roi romain germanique Lothaire $\mathrm{III}^{37}$, tout comme lors de l'impressionnante victoire du roi de Bohême Přemysl Otakar II face à l'armée bien plus puissante du roi de Hongrie Béla IV lors de la bataille de Kressenbrunn durant l'été $1260^{38}$. Il n'est donc guère étonnant que le 28 septembre soit devenu une fête nationale pour tous les Tchèques. Ce jour-là se déroulait régulièrement au Château de Prague l'assemblée du pays, suivie d'un banquet grandiose de plusieurs jours ${ }^{39}$. On célébrait ainsi dans l'ensemble de la Bohême, et de manière si enjouée, qu'en 1110, les Polonais en profitèrent pour faire une incursion avec leurs troupes loin dans l'arrière-pays tchèque, sans rencontrer le moindre problème ${ }^{40}$. Le rôle symbolique de saint Venceslas comme souverain éternel, non seulement du royaume de Bohême, mais de tous les pays de la Couronne tchèque, fut amené à un degré de perfection sous le règne de l'empereur Charles IV (1346-1378). A l'époque, la nouvelle couronne (de Saint-Venceslas) des rois de Bohême, en l'honneur de la majesté de Venceslas, fut déposée de façon permanente aux côtés de son crâne dans le trésor de la cathédrale pragoise. Le roi de Bohême avait le droit de l'emprunter au saint, c'est-à-dire au chapitre métropolitain, pour une somme de 300 pièces d'or, uniquement le jour de son couronnement ou lors de fêtes exceptionnelles, à la condition qu'il la replace ensuite sur la tête du saint ${ }^{41}$.

En Pologne, le culte de saint Venceslas n'atteignit jamais de telles proportions. En outre, il n'était pratiqué que dans certaines régions. Avant tout, dans la région de Cracovie, où lui avait été - comme déjà mentionné - consacrée une cathédrale, raison pour laquelle son nom apparait dans un des plus anciens pontificaux locaux datant des années 1050-1075 $5^{42}$. A contrario, le célèbre Codex Gertrudianus ${ }^{43}$, sou-

Sigmaringen 1977, p. 330-348; F. Graus, St. Adalbert und St. Wenzel. Zur Funktion der mittelalterlichen Heiligenverehrung in Böhmen [in:] Europa Slavica - Europa Orientalis. Festschrift für Herbert Ludat zum 70. Geburtstag, ed. K.-D. Grothusen, K. Zernack, Berlin 1980, p. 205-231; J. Žemlička, op. cit., ici p. 211-220.

37 Kanovník vyšehradský, FRB 2, ed. J. Emler, Praha 1874, p. 201-237, ici p. 204.

38 Př́běhy krále Přemysla Otakara II., ibidem, p. 308-335, ici p. 318-319.

39 J. Žemlička, ,Politický kalendář” přemyslovských Čech, „Český časopis historický” 1991, 89, p. $31-47$.

40 Cosmae Pragensis Chronica III/35, p. 206.

${ }^{41}$ Z. Hledíková, Postava svatého Václava ve 14. a 15. století [in:] Svatý Václav, ed. P. Kubín, p. 239-252, ici p. 241-242; K. Otavský, Svatováclavská koruna a její funkce [in:] Svatý Václav, p. $253-266$.

42 Cf. H. Wąsowicz, Litania do Wszystkich Świętych z najstarszego pontyfikatu biskupów krakowskich [in:] Peregrinatio ad veritatem. Studia ofiarowane profesor Aleksandrze Witkowskiej OSU z okazji 40-lecia pracy naukowej, ed. U. Borkowka, Cz. Deptuła, R. Knapiński, Z. Piłat, E. Wiśniowski, Lublin 2004, p. 357-570, ici p. 561.

43 Le codex se trouve aujourd'hui, sous la référence Cod. 136, au Muzeo Archeologico Nazionale de Cividale del Friuli. A ce propos cf. H.V. Sauerland, A. Haseloff, Der Psalter Erzbischof Egberts von Trier, Codex Gertrudianus in Cividale, Trier 1901 (édition du calendrier p. 37-42); I. Siede, Psalter Erzbischof Egberts von Trier [in:] Heiliges Römisches Reich deutscher Nation 962 bis 1806. Vom Otto dem Grossen bis zum Ausgang des Mittelalters, Ausstellungskatalog, ed. M. Puhle, C.-P. Hasse, Dresden 2006, p. 98. 
vent lié au culte de saint Venceslas à Cracovie, est davantage en lien avec Prague. Peu de temps avant la moitié du XII ${ }^{e}$ siècle, on inscrivit dans ce dernier un calendrier liturgique mentionnant la consécration de la cathédrale Saint-Venceslas, que certains historiens polonais identifient étant comme la cathédrale du Wavel ${ }^{44}$. En réalité, il s'agirait probablement de la cathédrale de Prague, car la date de la consécration indiquée est le 30 septembre, ce qui correspond à l'information du Moine de Sázava de $1143^{45}$. En outre, non seulement la fête de saint Venceslas y est-elle marquée en lettres d'or, mais également celle de sa grand-mère sainte Ludmila, qui n'était alors vénérée exclusivement qu'à Prague. Du reste, le martyre de Venceslas (28.09.) fut évidemment une fête obligatoire à Cracovie tout au long du Moyen-âge, et ce, à un haut niveau en tant que duplex ${ }^{46}$. De même, les biens du chapitre cathédral de Cracovie sont appelés terra s. Vencezlai dans les documents ${ }^{47}$. Jusqu'à la moitié du $\mathrm{XIII}^{\mathrm{e}}$ sièce, saint Venceslas occupait une place de premier ordre dans le panthéon des saints de Cracovie. En 1222 encore, l'évêque de Cracovie Iwo Odrowąż consacra le nouveau monastère cistercien de Mogila, près de Cracovie, à la Vierge Marie et à saint Venceslas ${ }^{48}$. La situatio changea toutefois après la canonisation de saint Stanislas, annoncée par le pape Innocent IV à Assise le 8 septembre 1253. A partir de ce moment-là, l'église épiscopale de Cracovie commença a être désignée comme la cathédrale Saint-Venceslas-et-Saint-Stanislas ${ }^{49}$. Les deux patrons étaient présentés dans le patrocicnum soit ensemble, soit séparément, et dans ce cas, uniquement saint Stanislas dans la majeure partie des $\operatorname{cas}^{50}$, et Venceslas rarement tout seul ${ }^{51}$. Le fait que la translation de saint Stanislas ait été fêtée le 27 septembre, soit la veille de sa propre fête, fut également un désavantage pour le culte de saint Venceslas. Le duc de Bohême ne pouvait que difficilement concurrencer le culte d'un évêque local dont la tombe se trouvait en outre au beau milieu de la cathédrale du Wawel. Mais il ne fut pas totalement évincé et resta non seulement le patron de la cathédrale, mais aussi de la dynastie Piast, comme en témoigne un écrit de Boleslas le Pudique daté de 1279,

44 Considérée comme la plus ancienne preuve du culte de saint Venceslas en Pologne par J. Rajman, Średniowieczne patrocinia krakowskie, Kraków 2002, p. 111. À propos du codex, cf. par ex. D. Leśniewska, Kodeks Gertrudy. Stan i perspektywy badań, „Roczniki Historyczne” 1995, 61, p. $141-170$.

45 Mnich sázavský, FRB 2, ed. J. Emler, Praha 1874, p. 238-269, ici p. 262. C'est ainsi que l'interprète J. Kalousek, Kalendár č českého pưvodu z prostředka 12. století, „Časopis Musea Království českého" 76, 1902, p. 159-165; I. Hlaváček, Przyczynek do czesko-polskich kontaktów książowych za panowania Przemyślidów, „Archiwa, Biblioteki i Muzea Kościelne” 1976, 33, p. 313-328, ici p. $322-323$.

46 H. Wąsowicz, Kalendarz ksiag liturgicznych Krakowa do połowy 16. wieku. Studium chronologiczno-typologiczne, Lublin 1995, p. 366-367; I. Skierska, Sabbatha sanctifices. Dzień święty w średniowiecznej Polsce, Warszawa 2008, p. 222.

47 J. Rajman, op. cit., p. 114, 190 (note 19 avec les références des sources).

48 Ibidem.

49 Mentionnée ainsi pour la première fois en 1258 (,....Wenczeslay et Stanislay pontificis Cracoviensis ecclesie patronorum...”), Kodeks dyplomatyczny katedry krakowskiej św. Wactawa [ci-dessous KDKK] 1, ed. F. Piekosiński, Kraków 1874, No 59, p. 74. Cf. J. Rajman, op. cit., p. 25.

50 Pour la première fois en 1278. KDKK 1, No 80, p. 107. Cf. J. Rajman, op. cit., p. 25.

51 Pour la liste des sources, cf. J. Rajman, op. cit., p. 25. 
où le duc désigne comme ses patrons Stanislas et Venceslas ${ }^{52}$. Enfin, aux alentours de 1300, les Přemyslides s'emparèrent à nouveau de la région de Cracovie, soutenant efficacement le culte de leur principal patron à travers l'évêque local Jan Muskata ${ }^{53}$.

Dans la Pologne médiévale, le culte de saint Venceslas ne se limitait pas uniquement au diocèse de Cracovie. La fête du martyre de saint Venceslas apparaît dans des livres liturgiques médiévaux plus tardifs comme étant obligatoire également dans les diocèses de Gniezno, Płock et Chełm ${ }^{54}$. Les évêques polonais demandèrent en 1217 au chapitre général des cisterciens de célébrer dans leurs monastères de Pologne les fêtes de saint Adalbert et Venceslas sous forme de rite en douze leçons (XII lectiones). Dans leur demande, les deux martyres sont désignés comme apôtres des Polonais ${ }^{55}$. En revanche, le nombre d'églises et chapelles Saint-Venceslas en Pologne était assez faible. On n'en dénombrait que quatre dans le diocèse de Cracovie ${ }^{56}$, trois dans celui de Gniezno ${ }^{57}$. Dans les autres diocèses, hormis la Silésie, leur nombre n'a pas été établi, mais il ne pouvait guère être supérieur.

Après la fin de la domination přemyslide en Pologne, saint Venceslas se retrouva quelque peu mal-aimé sous le règne de Ladislas $I^{\text {er }}$ le Bref. Les «statutes » de l'évêque de Cracovie Nanker, de 1320, éliminèrent la saint Venceslas des fêtes les plus importantes ${ }^{58}$. La longue rivalité des Etats tchèques et polonais eut en outre pour conséquence de rendre les Polonais plutôt réservés vis-à-vis de Venceslas ${ }^{59}$. Pourtant, sous le règne des Jagellons, son culte ressurgit à nouveau à Cracovie ${ }^{60}$, voire même atteignit son apogée. En 1436, lors du synode de Cracovie présidé par l'évêque Zbigniew Oleśnicki, il fut proclamé - aux côtés de saints Adalbert, Stanislas et Florian principal patron du royaume de Pologne ${ }^{61}$. Mais il faut prendre ceci avec circonspection, car cette proclamation n'eut aucune incidence sur les autres diocèses polonais.

52, „[...] patronorum nostrorum beatorum Wenceszlay et Stanizlay martirum [...]”, KDKK 1, No 81, p. 109. Cf. aussi J. Rajman, op. cit., p. 191.

53 À propos du soutien de Muskat au culte de saint Venceslas cf. A. Rożnowska-Sadraei, Pater Patriae. The Cult of Saint Stanislaus and the Patronage of Polish Kings 1200-1455, Kraków 2008, p. $130-164$.

54 I. Skierska, op. cit., p. 222-223.

55 „Petitio episcoporum Poloniae de festivitatibus Adalberti et Veneslais illius gentis apostolorum admittitur, ut scilicet omnis domus ordinis in illa regione cum XII lectionibus celebrat festum". Voir Statuta capitolorum generalium ordinis cisterciensis ab anno 1116 ad annum 1786 I, ed. J. Canivez, Louvain 1933, No 74, p. 482.

56 J. Rajman, op. cit., p. 285. A contrario, E. Wiśniowski (Z problematyki kultu świętych [in:] Peregrinatio ad veritatem, p. 571-578, ici p. 576) n'en mentionne qu'une seule !

57 W. Schenk, op. cit., p. 89.

58 W. Schenk, op. cit., p. 88; J. Rajman, op. cit., p. 191-192.

59 Cf. A. Giesztor, Politische Heilige im hochmittelalterlichen Polen und Böhmen [in:] Politik und Heiligenverehrung im Hochmittelalter, ed. J. Petersohn, Sigmaringen 1994, p. 325-341, ici p. 328.

${ }^{60}$ H. Wąsowicz, op. cit., p. 366.

${ }_{61}$ Cette proclamation concerne en premier lieu saint Florian - ,[...] ordinamus prenominatum gloriosum martyrem et patronum nostrum (Florianum) per totam nostram diocesim inter ceteros regni huius patronos insignes, videlicet Adalbertum, Stanislaum, Wenceslaum martyres pari devocione in horis canonicis et officiis divinis attollendum, colendum et venerandum [...]". Cf. S. Zachorowski, Statuty synodalne krakowskie Zbigniewa Oleśnickiego, Kraków 1915, p. 47. A ce propos cf. H. Sobeczko, 
La Silésie est un chapitre à part. En 1335, elle rejoint pour plus de 400 ans la Couronne tchèque, politiquement mais aussi culturellement ${ }^{62}$. Même l'évêché de Wrocław, quand bien même dépendait-il de Gniezno, était davantage orienté vers Prague. C'est pour cette raison que fut installée sur le porche de l'église de Wrocław une statue gothique de saint Venceslas ${ }^{63}$ et que l'évêque local Preczlaw (1341-1372) y fonda une église en l'honneur de saints Venceslas, Stanislas et Gothard ${ }^{64}$. Le roi de Bohême (et romain) Charles IV lui-même fonda à Wrocław en 1351 un monastère d'augustins-ermites, dédié à saints Venceslas, Stanislas et Dorothée ${ }^{65}$. Au XV $\mathrm{XV}^{\mathrm{e}}$ siècle, une autre église fut consacrée à Venceslas à Pniów près de Gliwice et un monastère minorite à Racibórz ${ }^{66}$. La fête du martyre et du transport de Venceslas apparaît alors régulièrement dans les livres liturgiques silésiens et son nom est mentionné dans les litanies à tous les saints. Il est intéressant de noter que le culte de saint Venceslas était le plus fort à Świdnica, qui fut le dernier duché de Silésie à rejoindre la Couronne tchèque en 1353. Saint Venceslas y était déjà apparu auparavant sur les pièces du duc Bernard de Świdnica (1301-1326), il était également le patron de la ville de Świdnica, tout comme le patron (depuis 1288) de l'église paroissiale (à partir de 1303, aux côtés de Stanislas ; depuis 2004, il s'agit de la cathédrale du nouveau diocèse) et de l'église de Marcinkowice non loin de là $(1307)^{67}$.

La même situation qu'en Silésie se retrouve en Haute Lusace voisine, qui faisait partie du fief tchèque depuis le $\mathrm{XII}^{\mathrm{e}}$ siècle et qui sous la dynastie des Luxembourg, rejoignit, avec la Basse Lusace la Couronne de Bohême pour longtemps. Le culte de saint Venceslas y était surtout pratiqué à Žitava (Zittau) où sa statue fut édifiée dans le dernier quart du XIVe siècle sur la façade de l'église paroissiale Saint-Jean-Baptiste ${ }^{68}$.

Kult liturgiczny św. Wacława na Śląsku w świetle średniowiecznych rękopisów liturgicznych, „Roczniki Teologiczno-Kanoniczne" 1967, 14, p. 55-81, ici p. 55; W. Schenk, op. cit., p. 88; H. Wąsowicz, op. cit., p. 366, et J. Rajman, op. cit., p. 192; J. Nastalska, Bonus et iustus. Święty Wacław $w$ 1. starostowiańskiej legendzie. Se nyny sbys't [in:] Peregrinatio ad veritatem, p. 325-344, ici p. 325.

${ }^{62}$ Cf. H. Sobeczko, op. cit.

63 R. Kaczmarek, Umění ve Slezsku, umění v českých zemích a lucemburský mecenát: Mezi svízelným dédictvím a bezvýhradným príietím? [in:] Slezsko, perla v české koruně. Historie - kultura umění, ed. M. Kapustka, J. Klípa, A. Kozieł, P. Oszczanowski, V. Vlnas, Praha 2007, p. 115-147, ici p. 133, (ill. 15) et p. 135; J. Kuthan, K šírení kultu svatého Václava za hranice Čech a Moravy v době Přemyslovců a Lucemburků [in:] Svatý Václav, ed. P. Kubín, p. 221-238, ici p. 223; J. Royt, Ikonografie svatého Václava ve středověku [in:] Svatý Václav, p. 301-327, ici p. 312 et ill. 5; A. Mudra, Královské atributy ve středověké ikonografii svatého [in:] Svatý Václav, p. 329-344, ici p. 329 et ill. 2.

${ }_{64}$ H. Sobeczko, op. cit., p. 60.

${ }_{65}$ Chr. Reisch, Geschichte des Klosters und der Kirche St. Dorothea in Breslau, Wrocław 1908, p. 11-12. Dans la confirmation de Charles IV de 1361, il n'est appelé que monastère Saint-Venceslas (ibidem p. 382), mais à Wrocław même, il était au contraire appelé (à partir du XVIe siècle) monastère Sainte-Dorothée.

${ }^{66}$ H. Sobeczko, op. cit., p. 60-62.

${ }^{67}$ H. Sobeczko, op. cit., p. 62-81; A. Barciak, W sprawie kultu św. Wactawa na Ślasku w XIII w. [in:] idem, Między Polskq a Czechami. Śląsk i jego mieszkańcy w źródłach czeskich doby średniowiecza, Wrocław 2012, p. 177-188.

68 Aujourd'hui, la statue se trouve au Städtische Museen Zittau, No d'id. 10631/32241. Pour plus d'informations cf. H. Schwerdel-Schmidt, Der heilige Wenzel [in:] Zeit und Ewigkeit. 128 Tage in St. Marienstern, Ausstellungskatalog, ed. J. Oexle, Halle a. d. Saale 1998, p. 261-262. 
Non loin de là, au château d'Ojvíň, l'empereur Charles IV fonda un monastère de célestins en l'honneur de Notre-Dame, de saint Venceslas et saint Pierre le Confesseur $(1366)^{69}$.

Charles IV fut le plus grand propagateur du culte de saint Venceslas. Il rédigea lui-même une nouvelle légende dédiée à saint Venceslas (Crescente religione /8842-8843/) dédiée à la lecture de bréviaire ${ }^{70}$. Quand son père Jean de Luxembourg était encore en vie (1339), Charles fit en sorte que le symbole de saint Venceslas représentant un aigle enflammé, libéré après l'extinction de la dynastie des Přemyslides, fut attribué à l'évêché de Trente. A cette époque, les Luxembourg s'efforçaient d'avoir le dessus sur les Wittelsbach dans le Tyrol voisin ${ }^{71}$. Ils exprimèrent leurs revendications de pouvoir par une fresque représentant saint Venceslas dans l'église paroissiale Notre-Dame à Bolzano ${ }^{72}$. Mais c'est dans les territoires impériaux, destinés à rejoindre la Couronne de Bohême, que l'empereur concentra ses principaux efforts. Il s'agissait tout d'abord de ce qu'on appelait la Nouvelle Bohême (Neuböhmen), un espace situé entre la Forêt de Bohême et Nuremberg, où Charles IV fit édifier un vaste système de fiefs tchèques. Sulzbach devint la ville principale de cette région, où le pouvoir tchèque était symbolisé par une statue de saint Venceslas, placée sur la façade extérieure de l'église Notre-Dame ${ }^{73}$. C'est aussi de Sulzbach que Charles IV entama son défilé romain pour aller chercher sa couronne impériale et ce, de manière symbolique, en partant le jour de la saint Venceslas, le 28 septembre $1354^{74}$. Dans cette même région, il fit également construire à Lauf an der Pegnitz un nouveau château dédié à saint Venceslas (Wenzelsburg), dont le portail d'entrée est aujourd'hui encore gardé par une statue gothique de Venceslas ${ }^{75}$. A Nuremberg même, l'empereur dédia un autel à Venceslas (et à d'autres saints) dans la nouvelle église Notre-Dame (Frauenkirche) située sur la place principale ${ }^{76}$. Quand en 1371, Charles IV échangea avec les Wittelsbach la Nouvelle Bohême contre le Brandebourg, le culte de Venceslas se propagea également dans cette région du nord de l'Allemagne. En 1375, l'empereur fit installer l'Autel de Bohême dans la cathédrale de

69 R. Němec, Caroli IV. Imperatoris Romani Fundatio: Kostel kláštera Celestinů na Ojvíně u Žitavy, „Průzkumy památek” 2004, 11, p. 3-52.

70 A. Blaschka, Die St. Wenzelslegende Kaiser Karls IV., Einleitung, Texte, Praha 1934. A ce propos cf. Z. Hledíková, Postava svatého Václava ve 14. a 15. století [in:] Svatý Václav, p. 239-252, ici p. 243-245.

71 Hledíková, Postava svatého Václava..., p. 239-241.

72 J. Weingartner, Die Kunstdenkmäler Südtirols 2 - Bozen und Umgebung, Bozen-InnsbruckVienne 1991, p. 15; R. Meluzínová, Krasný sloh a jižní Tyroly, Praha 2017.

73 P. Chotěbor, Kostel Panny Marie v Sulzbachu v souvislostech karlovského umění, „Umění” 2003, 51, p. 506-509.

74 K. Kubínová, Imitatio Romae. Karel IV. a Řím, Praha 2006, p. 77.

75 J. Kuthan, op. cit., p. 226 (ill. 2); A. Mudra, op. cit., p. 330 et 337 (ill. 5).

76 F. Machilek, Privatfrömmigkeit und Staatsfrömmigkeit [in:] Kaiser Karl IV. Staatsmann und Mäzen, ed. F. Seibt, München 1978, p. 87-101, ici p. 100. 
Brandebourg-sur-la-Havel. Sur ses pans extérieurs sont représentés les saint patrons tchèques, dont saint Venceslas ${ }^{77}$.

En 1365, le pape Urbain V accorda aux métropolitains de Prague la fonction privilégiée de légats du pape permanents pour les évêchés voisins de la ville de Meissen, Bamberg et Ratisbonne ${ }^{78}$. La Saint-Venceslas devint donc obligatoire également dans ces diocèses, ainsi que le rappelle de façon claire l'édit provincial de l'archevêque de Prague Jean de Jenstein datant d'avril $1381^{79}$. Du point de vue impérial, ce sont les fondations d'autels Saint-Venceslas dans les centres idéologiques impériaux par Charles IV qui s'avèrent les plus importantes, et ce, dans la chapelle mariale d'AixlaChapelle $^{80}$ et dans la basilique Saint-Pierre à Rome ${ }^{81}$. En ces lieux, ce ne sont pas uniquement les pèlerins de l'empire qui pouvaient ainsi découvrir saint Venceslas, mais ceux de l'Europe toute entière. Entretemps, son culte se propagea également dans d'autres régions germaniques, comme la Thuringe ${ }^{82}$, l'Anhalt ${ }^{83}$, ou plus tard la Souabe ${ }^{84}$, et - comme nous le savons par des recherches fortuites - plus loins à l'Ouest également ${ }^{85}$.

A la fin du Moyen-âge, cette expansion du culte alla de pair, notamment en Bohême, avec une homilétique liée à saint Venceslas. On y a découvert environ 150 sermons pour la fête de saint Venceslas, orientés sur sa fonction de souverain, sa piété eucharistique, son sentiment social ou l'importance des saints de manière

77 E. Wetter, Bývalý hlavní oltáŕni retábl z dómu v Brandenburgu [in:] Karel IV. Císař z boži milostí. Kultura a uméní za vlády Lucemburků 1310-1437, ed. J. Fajt, Praha 2006, p. 352-355; J. Kuthan, op. cit., p. 229; J. Royt, op. cit., p. 312 ; A. Mudra, op. cit., p. 336 et 340 (ill. 8).

78 Z. Hledíková, Die Prager Erzbischöfe als ständige päpstliche Legaten. Ein Beitrag zur Kirchenpolitik Karls IV. [in:] Regensburg und Böhmen, red. G. Schwaiger, J. Staber, Regensburg 1972, p. 221-256.

79 Pražské synody a koncily předhusitské doby, ed. J.V. Polc, Z. Hle díková, Praha 2002, p. 214 215. Cf. Z. Hledíková, Postava svatého Václava ..., p. 242-243.

80 H.P. Hilger, Der Altar des Hl. Wenzel im Dom zu Aachen, „Aachener Kunstblätter” 1973, 44, p. 211-232.

81 P.C. Clausen, Der Wenzelalter in Alt St. Peter. Heiligenverehrung, Kunst und Politik unter Karl IV., „Zeitschrift für Kunstgeschichte” 1980, 43, p. 280-299.

82 En Thuringe, dans les manuscrits liturgiques, le jour de la saint Venceslas est désigné comme une fête de trois leçons. Cf. P. Kubín, Čeští světci ve středověkých rukopisech Durynska /Jena-Gotha-ErfurtVýmar/, „Acta Universitatis Carolinae - Philosophica et historica 1995 (= Z pomocných věd historických 12)", p. 9-71.

83 Dans l'Anhalt, sur la rivière Saale, il s'agit des églises Saint-Venceslas de Könnern et Naumburg. Dans les deux églises se trouvent des fonts baptismaux du Bas Moyen-âge arborant un relief de saint Venceslas. Cf. A. Mudra, op. cit., p. 330 et 338-339 (ill. 6 et 7).

${ }^{84}$ Il s'agit d'un autel à panneaux (1385) avec saints Venceslas, Guy et Sigismond pour la chapelle Saint-Guy à Mühlhausen près de Stuttgart. Cf. E. Rettich, R. Klapproth, G. Ewald, Alte Meister. Staatsgalerie Stuttgart. Austellungskatalog, Stuttgart 1992, p. 304-311.

${ }_{85}$ P. Kubín, Svátky českých světců ve středověkých rukopisech pařižské Bibliothèque nationale de France, Sborník Katolické teologické fakulty 4, ed. M. Mikulicová, P. Kubín, Praha 2002, p. 344 422; P. Ku bín, Svátky českých světců ve středověkých rukopisech francouzských knihoven a ,kanonizační akta" sv. Vojtěcha v Pařiži, Sborník. Katolické teologické fakulty 7, ed. P. Kubín, M. Mikulicová, D. Svoboda, Praha 2005, p. 270-284. 
générale ${ }^{86}$. On ne s'étonnera donc guère que le prénom Venceslas ait fait partie des favoris en Bohême ${ }^{87}$. Le culte de saint Venceslas était si fort en pays tchèques que même l'époque hussite ne représenta pas une grosse rupture dans sa vénération. Au contraire, les Hussites pragois menacés en 1420 par une armée de croisés invoquèrent saint Venceslas pour lui demander de les aider à défendre la ville. C'est d'ailleurs probablement à cette époque qu'a été composé un nouveau couplet de l'ancien chant à saint Venceslas, dans lequel on en appelle à Venceslas - nedej zahynouti, nám ni budoucím! (ne permets pas que l'on périsse, ni nous ni nos descendants), un couple chanté plus tard par les catholiques également ${ }^{88}$. Seuls les plus radicaux des Hussites vouaient Venceslas et les autres saints aux gémonies, la frange plus modérée d'entre eux refusant d'abandonner le saint patron du pays. Les utraquistes majoritaires, qui se considéraient comme des membres orthodoxes de l'église catholique, n'avaient aucun problème à vénérer saint Venceslas. Son culte était également pratiqué à Kutná Hora qui était un des centres de l'utraquisme ${ }^{89}$. Dans certaines églises utraquistes, saint Venceslas était représenté sur l'autel aux côtés de maître Jan Hus ${ }^{90}$.

La vénération continue de saint Venceslas en Bohême utraquiste ne pouvait évidemment pas empêcher qu'il soit également vénéré dans le reste de l'Europe catholique romaine, ni que son culte ne se propage davantage. $\mathrm{Au} \mathrm{XV}$ siècle, on le retrouve ainsi nouvellement à Passau, Freising, Eichstätt (ici, dès le XII ${ }^{\mathrm{e}}$ siècle), Worms, Spire, Colmar, Cologne, ou non loin de là, à Neuss. La liturgie honorant saint Venceslas était en général célébrée au niveau de trois leçons (III lectiones), soit dans la moitié inférieure de la hiérarchie des fêtes à l'époque. Là encore, il s'agissait la plupart du temps de monastères issus d'ordres prédicateurs ${ }^{91}$.

Le culte de saint Venceslas pénétra également de manière marginale en Hongrie, particulièrement dans le diocèse de Zagreb. Il semblerait que cela ait été le cas dès le premier évêque de Zagreb, Duch (1094), qui était probablement d'origine tchèque. La fête de saint Venceslas (et de saint Adalbert) y apparaît dans les manuscrits liturgiques des $\mathrm{XIV}^{\mathrm{e}}$ et $\mathrm{XV}^{\mathrm{e}}$ siècles ${ }^{92}$. Sur l'île croate de Krk, qui apppartenait à la république de Venise, on conservait au XIII ${ }^{\mathrm{e}}$ siècle, dans l'église paroissiale d'Omišalj, un reliquaire comtenant des reliques de saint Venceslas et sainte Ludmila ${ }^{93}$. Enfin,

86 Z. Uhlír, Literární prameny svatováclavského kultu a úcty ve vrcholném a pozdním středověku, Praha 1996, p. 18-34; Z. Hledíková, op. cit., p. 245-246.

87 E. Doležalová, Svěcenci pražské diecéze 1395-1416, Praha 2010, p. 128.

88 Z. Hledíková, op. cit., p. 246; F. Šmahel, Úcta ke svatému Václavu v husitských Čechách [in:] Svatý Václav, ed. P. Kubín, p. 281-299, ici p. 286-287.

89 M. Ottová, Zobrazení svatého Václava za vlády Jagellonců v českých zemích [in:] Svatý Václav, ed. P. Kubín, p. 345-362, ici p. 353-355.

90 Les lieux sont précisés par F. Šmahel, op. cit., p. 293. Pour plus d'informations sur le retable de Roudník près d'Ústí n/L (avant 1486) cf. M. Bartlová, Kř́dla retáblu z Roudník [in:] Uměni české reformace /1380-1620/, ed. K. Horníčková, M. Šroněk, Praha 2010, p. 136-137.

91 Cf. note No 85.

92 D. Kniewald, Zagrebački liturgijski kodeksi XI. - XV. stoljeća, Zagreb 1940, passim.

93 V. Čermák, Ke kořenům cirkevněslovanského písemnictví kláštera Na Slovanech [in:] Karel IV. a Emauzy. Liturgie, text a obraz, ed. K. Kubínová, Praha 2017, p. 16-29, ici p. 21. 
le manuscrit le plus ancien arrivé jusqu'à nous, Les premières légendes slavones sur saint Venceslas, datant des XIV et $\mathrm{XV}^{\mathrm{e}}$ siècles, viennent également de Croatie $^{94}$.

\section{SAINT ADALBERT}

L'ancien évêque de Prague Adalbert fut assassiné par des païens au début de sa mission en Prusse, le vendredi 23 avril 997. Selon de nombreux historiens, Adalbert fut canonisé deux ans plus tard à Rome par le pape Sylvestre $\mathrm{II}^{95}$. On considère comme la date la plus probable le 29 juin 999, soit le jour anniversaire de la consécration d'Adalbert en tant qu'évêque, quand bien même il n'existe aucune source le confirmant ${ }^{96}$. Le dernier à avoir essayé de prouver la date de la canonisation d'Adalbert, est Gerard Labuda, et ce sur la base d'une analogie avec la constitution d'un culte en l'honneur de cinq frères saints, torturés en Pologne en novembre $1003^{97}$. D'après la légende rédigée à leur propos par leur ancien camarade Bruno de Querfurt, c'est le pape Jean XVIII lui-même qui ordonna qu'ils fussent vénérés comme des saints $^{98}$. Mais le silence de ce même auteur, Bruno donc, dans la Vita altera d'Adalbert (Nascitur purpureus flos /BHL 38ab/), à propos d'un même ordre de Sylvestre II vis-à-vis d'Adalbert, témoigne du fait que cette thèse est caduque. Si un tel ordre avait été donné, Bruno n'aurait certainement pas manqué de le souligner ${ }^{99}$. En réalité, Adalbert fut proclamé saint uniquement par sa translation ordonnée par Boleslas I ${ }^{\text {er }}$

94 J. Vaj s, Nejstarši breviár chrvatsko-hlaholský, Praha 1910, p. XIV-XVI, XXI-XXV, XLV-LII; Sborník staroslovanských památek o sv. Václavu a sv. Lidmile, ed. J. Vajs, Praha 1929, p. 31.

${ }_{95}$ Ainsi mentionné par les plus importantes monographies consacrées à Adalbert, et d'autres études: H.G. Voigt, Adalbert von Prag. Ein Beitrag zur Geschichte der Kirche und Mönchtums im zehnten Jahrhundert, Weltend-Berlin 1898, p. 195; F. Krás1, J. Ježek, Sv. Vojtěch, druhý biskup pražský, jeho klášter i úcta u lidu, Praha 1898, p. 213-217; R. Holinka, Svatý Vojtěch, Brno 1947, p. 115; M. Uh1irz, Jahrbücher des Deutschen Reiches unter Otto II. und Otto III., Bd. 2: Otto III. 983-1002, Berlin 1954, p. 311; J. Karwasińska, Wojciech-Adalbert [in:] Hagiografia Polska, Stownik bio-bibliograficzny 2, Poznań-Warszawa-Lublin 1972, p. 572-589, ici p. 584-585; G. Labuda, Święty Wojciech. Biskup - męczennik. Patron Polski, Czech i Wẹgier, Wrocław 2000, p. 227-236; A. Pobóg-Lenartowicz, Najstaršie Životy sv. Vojtecha. Vitae s. Adalberti [in:] J. Nemeš, R. Kožiak et al., Svätý Vojtech-svätec, doba a kult, Bratislava 2011, p. 33-54.

96 „Consecratus ille festo amicorum Domini nostri Jesu Christi, Petri et Pauli”. S. Adalberti Pragensis, episcopi et martyris Vita prior /ci-dessous Vita prior/, Monumenta Poloniae Historica, Series Nova [ci-dessous MPH s.n.] 4/1, ed. J. Karwasińska, Warszawa 1962, c. 8, p. 13; M. Uhlirz, op. cit., p. 311.

97 G. Labuda, Kanonizacja świętego Wojciecha, „Kwartalnik Historyczny” 2005, 112, No. 3, p. 33-40.

98, ,...] papa procul dubio iussit eos in loco sanctorum martyrum haberi et honorari [...]", Vita quinque fratrum eremitarum seu Vita vel Passio Benedicti et Iohannis sociorumque suorum auctore Brunone Querfurtensi (= MPH s. n. 4/3), ed. J. Karwasińska, Warszawa 1973, c. 21, p. 71.

99 S. Adalberti Pragensis episcopi et martyris Vita altera auctore Brunone Querfurtensi (= MPH s. n. 4/2), ed. J. Karwasińska, Warszawa 1969. 
le Vaillant, avec l'accord de l'évêque de Poznań Unger, dès l'été $997^{100}$. D'après une légende anonyme sur le martyre de saint Adalbert, Passio de Tegernsee (BHL 40), rédigée en Pologne un peu avant 1039, Boleslas Ir le Vaillant fit solennellement transporter les reliques du saint à Gniezno ${ }^{101}$, où il les déposa dans la nouvelle abside de l'église castrale Notre-Dame ${ }^{102}$. Contrairement à saint Venceslas, Adalbert ne dut pas attendre des dizaines d'années sa gloire posthume. Son culte commença à se diffuser pratiquement immédiatement, non seulement en Pologne, mais aussi dans tout l'empire médiéval. C'est en effet grâce à la volonté de l'empereur Otton III en personne, qui entretenait avec Adalbert une amitié pleine de confiance. La diffusion du culte d'Adalbert s'effectua ainsi à partir d'un plan réfléchi, préparé par l'empereur lui-même à l'aide d'un cercle de ses plus proches conseillers, dont la majeure partie connaissait personnellement Adalbert. L'outil le plus important de cette propagande fut la rédaction d'une hagiographie consacrée à Adalbert, que nous connaissons aujourd'hui sous le titre de Vita prior (Est locus /BHL 37/). Sa première version, dite ottonienne, fut rédigée dès les alentours de l'an 1000, vraisemblablement sur ordre d'un des conseillers d'Otton, l'évêque de Liège Notger ${ }^{103}$.

Le second outil de propagande fut la fondation bien organisée d'églises dédiées au martyr dans des lieux importants de l'empire romain. Les deux premières églises virent le jour dès 997 sur le territoire du diocèse de Liège, à Aix-la-Chapelle et Liège. L'église d'Aix-la-Chapelle fut édifiée par Otton III hors des murailles de la ville, pour le nouveau chapitre collégial, celle de Liège par l'évêque Notger pour servir d'église paroissiale d'un nouveau quartier sur l'Ile de la Cité, entre les bras de la Meuse. Un ou deux ans plus tard, l'empereur fonda une autre église Saint-Adalbert à Rome sur l'île Tibérine, sous l'Aventin, où Adalbert avait passé plusieurs années en tant que moine au monastère Saints-Boniface-et-Alexis. Cette église, bien qu'elle fût une grande basilique, était censée servir de chapelle privée à l'empereur. En 999, Otton III fit construire une petite église Saint-Adalbert dans le village d'Affile (près de Subiaco, à l'est de Rome), où l'on dit que saint Benoît aurait accompli son premier miracle. Elle appartint d'abord au monastère voisin de Comunacque, puis à partir de 1005 à celui de Subiaco. L'année suivante, en venant de Gniezno, l'empereur visita le monastère de l'île de Reichenau sur le lac de Constance, et y fonda une autre église Saint-Adalbert. Elle faisait partie de tout un ensemble conventuel et se trouvait non loin de l'église abbatiale principale de Mittelzell. C'est ici également (probalement encore du vivant d'Otton) que vit le jour le plus ancien chant liturgique connu à la

100 P. Kubín, Svatořečeni biskupa Vojtěcha [in:] Kościót w monarchiach Przemyślidów i Piastów, ed. J. Dobosz, Poznań 2009, p. 99-103.

101 Passio Adalberti episcopi martyris, ed. G. Waitz, MGH SS 15/2, Hannover 1888, p. 705-708.

102 A ce propos, cf. T. Janiak, Problematyka wczesnych faz kościoła katedralnego w Gnieźnie [in:] Początki architektury monumentalnej w Polsce, ed. T. Janiak, D. Stryniak, Gniezno 2004, p. 85-130, ici p. 96-109, p. 121; L. Wetesko, Historyczne konteksty monarszych fundacji artystycznych w Wielkopolsce do początku XIII wieku, Poznań 2009, p. 102-114, 309.

103 J. Fried, Gnesen-Aachen-Rom. Otto III. und der Kult des hl. Adalbert. Beobachtungen zum älteren Adalbertsleben [in:] Polen und Deutschland vor 1000 Jahren. Die Berliner Tagung über den „, Akt von Gnesen”, ed. M. Borgolte, Berlin 2002, p. 235-279, ici p. 241-25; J. Hoffmann, Vita Adalberti. Früheste Textüberlieferungen der Lebensgeschichte Adalberts von Prag, Essen 2005, p. 78-121. 
gloire de saint Adalbert, la séquence Annua recolamus sancti Adalberti gaudia. Enfin, la dernière église Saint-Adalbert fut fondée par Otton III, encore une fois pour une communauté monastique, cette fois-ci pour les ermites bénédictins de Pereo près de Ravenne, en 1001. L'église conventuelle avait la forme d'une rotonde avec des colonnes en marbre et se trouvait (à nouveau) sur une île dans le delta du Pô médiéval. Otton III n'eut plus l'occasion de faire édifier d'autres églises car il mourut en janvier 1002 à l'âge de seulement 21 ans ${ }^{104}$. Après la mort prématurée de l'empereur, le culte de saint Adalbert ne se diffusa plus dans l'empire, voire assez vite disparut presque totalement en Italie. La petite église d'Affile n'était déjà plus appelée qu'angélique en 1013 (c'est-à-dire dédiée à saint Michel), soit son second patrocinium, et les Romains renommèrent la basilique de l'île Tibérine Saint-Barthélémy (San Bartolomeo all'Isola) autour de la moitié du XII ${ }^{\mathrm{e}}$ siècle. Ce n'est qu'à Pereo que l'église ottonienne resta dédiée à saint Adalbert jusqu'au début du XVII siècle, où son patrocinium fut transféré vers la nouvelle église du village voisin de San Alberto, qui existe encore de nos jours (elle a été remaniée au cours de la seconde moitié du $\mathrm{XIX}^{\mathrm{e}}$ siècle). De même, il existe toujours une église Saint-Adalbert à Aix-la-Chapelle tandis que celles de Liège et Reichenau ont été démolies au cours du XIX ${ }^{e}$ siècle.

Dans l'idée d'Otton III, il y avait aussi une tentative de faire du culte de son cher ami une sorte clef de voûte politico-ecclésiastique entre l'empire et ses voisins orientaux. C'est pour cette raison qu'il se rendit personnellement à Gniezno en mars de l'an 1000, afin d'annoncer sur la tombe d'Adalbert la création d'une province ecclésiastique polonaise indépendante, à la tête de laquelle il plaça le frère d'Adalbert, Radim-Gaudencius en tant que métropolite de Gniezno ${ }^{105}$. Dans le même temps, il distingua Boleslas I ${ }^{\text {er }}$ le Vaillant d'une couronne (royale?) et du titre de cooperator imperii et amicus populi Romani ${ }^{106}$. Adalbert devint ainsi le symbole de la naissance de l'organisation ecclésiastique polonaise et du royaume de Pologne, de même que le principal saint patron de l'Etat de la dynastie des Piasts. Le vol des reliques d'Adalbert par le duc de Bohême Břetislav Irr, durant l'été 1039, dans le cadre d'une expédition guerrière en Pologne, n'y changea rien ${ }^{107}$. Bien que les reliques d'Adalbert aient été déposées dans la cathédrale de Prague, on retrouva près de 90 ans plus tard à Gniezno le « vrai » crâne du saint ${ }^{108}$. La trouvaille faite en Pologne avait été remar-

104 Pour les références des sources concernant les différentes fondations, cf. P. Kubín, Sedm přmyslovských kultů..., p. 173-189.

105 A ce propos, cf. par ex. J. Strzelczyk, Das Treffen in Gnesen und die Gründung des Erzbistums Gnesen [in:] Europas Mitte..., p. 494-497; R. Michałow ski, Zjazd Gnieźnieński. Religijne przesłanki powstania arcybiskupstwa gnieźnieńskiego, Wrocław 2005.

106 Galli Anonymi cronicae et gesta ducum sive principum Polonorum, MPH n. s. 2, ed. K. Małeczyński, Kraków 1952, p. 19-20.

107 Mentionné dans Cosmae Pragensis Chronica II,4-5, p. 85-91.

108 Le texte „Invencio capitis sancti Adalberti” de 1127 se trouve dans les annales de Traski et celles de Cracovie (Rocznik Traski i krakowski, ed. A. Bielow ski, MPH 2, Lwów 1872, p. 826-861, ici p. 832), qui reprenaient les informations des plus anciennes annales du chapitre de Cracovie, appelées Les annales de Rycheza. Il est aussi mentionné dans les annales de Petite-Pologne (Rocznik małopolski, ed. A. Bielowski, MPH 3, Lwów 1878, p. 135-202, ici p. 153). A ce propos cf. G. Labuda, Święty Wojciech, p. 273, note No 567. 
quée à Prague également ${ }^{109}, \mathrm{c}^{\prime}$ est pourquoi le crâne d'Adalbert dut également y être redécouvert «par précaution ${ }^{110}$. Les importantes vagues du culte de saint Adalbert furent également promptement exploitées par les augustins dans leur nouveau monastère de Trzemeszno en Pologne, fondé aux alentours de 1130 par le duc Boleslas III Bouche-Torse et sa femme Salomé ${ }^{111}$. Peu de temps après la fondation du monastère, les Augustins rédigèrent la légende d'Adalbert intitulée Tempore illo (BHL 42), selon laquelle un monastère se serait déjà trouvé en ces lieux (cenobium Cheremusen) dès la fin du $\mathrm{X}^{\mathrm{e}}$ siècle. En rachetant les reliques d'Adalbert aux Prussiens, Boleslas Ir le Vaillant les aurait tout d'abord déposées dans ce dernier, avant de les rapatrier à Gniezno ${ }^{112}$. C'est pour cette raison que le nouveau monastère augustin fut consacré à saint Adalbert et son culte y fut pratiqué avec ferveur, presque jusqu'à nos jours ${ }^{113}$. Ce n'est qu'après un grand chantier de fouilles archéologiques réalisé à a fin du $\mathrm{XX}^{\mathrm{e}}$ siècle qu'on démontra qu'il n'y avait eu aucun monastère avant celui des augustins ${ }^{114}$.

Boleslas ${ }^{\text {er }}$ le Vaillant lui-même fonda vraisemblablement la première église Saint-Adalbert dans le hameau marchand situé dans l'enceinte extérieur de Cracovie (l'actuel Rynek Główny). Il était destiné à l'administration spirituelle du diocèse. Son patrocinium n'est certes documenté qu'à partir de la moitié du XIII ${ }^{\mathrm{e}}$ siècle $^{115}$, où $s$ 'y trouvait déjà une église romane en pierre, mais il était probablement déjà existant lorsqu'il ne s'agissait encore que d'un bâtiment en bois aux alentours de l'an $1000^{116}$. Selon Roman Michałowski, Boleslas I ${ }^{\text {er }}$ le Vaillant ou un de ses successeurs directs (Mieszko II, voire éventuellement Casimir ${ }^{\text {er }}$ le Restaurateur) imitait consciemment les fondations d'Otton III à Aix-la-Chapell ${ }^{117}$. Bientôt, peut-être bien encore au XI ${ }^{\mathrm{e}}$ siècle, virent le jour de nouvelles églises Saint-Adalbert dans d'autres châteaux centraux de la dynastie des Piasts (ou dans leurs environs), comme à Poznań, Kalisz,

109 „Anno dominicae incarnationis 1127, VII Kalend. Martii, caput sancti Adalberti martyris et pontificis in civitate Gnezden repertum est, eo quidem loco, ubi martyr idem martyrio fuit coronatus et tumulatus". Kanovnik vyšehradský, p. 205.

110 „Eodem anno (1143) inventio capitis sancti Adalberti et episcopi et martyris in urbe Praga in ecclesia sancti Viti martyris, et cilicium sancti Wencezlai inventum est”. Mnich sázavský, p. 261-262.

111 Boleslas III Bouche-Torse fit également frapper de la monnaie avec une représentation de saint Adalbert. Cf. B. Paszkiewicz, op. cit., p. 143-145.

112 De s. Adalberto, episcopo Pragensi, ed. M. Perlbach, MGH SS 15,2, Hannover 1886, p. 11771184, ici p. 1183.

113 K. Józefowiczówna, Trzemeszno. Klasztor św. Wojciecha $w$ dwóch pierwszych wiekach istnienia, Warszawa-Poznań 1978, pensait encore qu'Adalbert n'y avait pas été seulement inhumé, mais qu'il avait lui-même fondé ce monastère en se rendant en mission en Prusse.

114 J. Chudziakowa, Z badań nad architektura sakralna w Trzemesznie (z lat 1987-1988), „Acta Universitatis Nicolai Copernici, Archeologia 20 - Nauki Humanistyczno-Społeczne” 1992, 244, p. 9-20; M. Wiewióra, Zespót klasztorny kanoników regularnych $w$ Trzemesznie $w$ świetle badań archeologiczno-architektonicznych, Toruń 2000.

115 J. Rajman, op. cit., p. 60.

116 K. Radwański, Kraków przedlokacyjny. Rozwój przestrzenny, Kraków 1975, p. 177-178; J. Wyrozumski, Dzieje Krakowa. Kraków do schyłku wieków średnich, Kraków 1992, p. 69.

117 R. Michałowski, Princeps fundator. Studium z dziejów kultury politycznej w Polsce X-XIII wieku, Warszawa 1993, p. 71-105. 
Opole ${ }^{118}$, au cours de la première moitié du XII ${ }^{\mathrm{e}}$ siècle, à Wroctaw et par la suite des dizaines d'autres en d'autres lieux dans toute la Pologne ${ }^{119}$.

A la fin du Moyen-âge, le martyre de saint Adalbert le 23 avril était célébré comme une fête obligatoire (festum fori) dans les diocèses de Gniezno, Cracovie, Poznan, Wrocław et Płock $^{120}$. En 1420, l'archevêque de Gniezno Mikołaj Trąba rendit cette fête obligatoire dans tous les diocèses de sa province ${ }^{121}$. Parce que le 23 avril correspond également à une fête importante, la saint Georges, on célébrait ainsi soit les deux saints en même temps, soit celle de Georges était reportée au jour suivant dans certains diocèses ${ }^{122}$. En outre, dans la plupart des diocèses polonais au Moyen-âge (Gniezno, Cracovie, Poznań, Włocławek et Płock), on fêtait également le 20 octobre la translation d'Adalbert liée à la découverte de ses reliques à Gniezno, dont la date hypothétique devait être située avant $1090^{123}$. A contrario, en Silésie (et également dans le diocèse de Lubusz), rattachée au royaume de Bohême à partir du XIV siècle, la translation d'Adalbert était célébrée selon le modèle tchèque le 25 août. Un siècle plus tard, elle fut déplacée au lendemain, soit au 26 août, en raison de sa collision avec la nouvelle fête de la translation de sainte Edwige de Silésie ${ }^{124}$.

La fête tchèque rappelait le rapatriement solennel des reliques volées de saint Adalbert, de Gniezno à Prague en $1039^{125}$. Selon la Chronique de Cosmas, cette année-là, le jour de la saint Barthélémy (= 24 août), la procession partit de la campagne environnante pragoise (aujourd'hui, le quartier de Vysočany) en direction du Château de Prague. A sa tête se trouvait le duc Břetislav I ${ }^{\text {er }}$ en personne ainsi que l'évêque de Prague Severus, portant tous deux les reliques d'Adalbert avant de les déposer de concert dans la cathédrale Saint-Guy ${ }^{126}$. En raison de la fête de l'apôtre Barthélémy, on déplaça ensuite d'une journée la célébration de cette translation. Par cet événement, Adalbert devint - aux côtés de saint Venceslas - le deuxième saint patron des pays tchèques. Dans les années 1060-1096, on fit construire une nouvelle cathédrale romane en lieu et place de l'ancienne rotonde Saint-Guy, dont le patrocinium fut élargi à saints Venceslas et Adalbert ${ }^{127}$. C'est pour cette raison que dans sa chronique, Cosmas fait prononcer à la princesse mythologique Libuše une prophétie à propos de deux olives dorées au Château de Prague, qui monteront jusqu'au septième ciel. La première étant dénommée Maior Gloria = Venceslas, la seconde Exercitus Conso-

118 W. Danielski, Z dziejów kultu liturgicznego św. Wojciecha na ziemach polskich. Święta ku czci św. Wojciecha, „Roczniki Teologiczno-Kanoniczne” 1967, 14, p. 83-111, ici p. 84-85.

119 Leur liste ainsi que les références bibliographiques sont mentionnées par R. Godula, ,Onego czasu, gdy święty Wojciech...", czyli rzecz o mityzacji Stawnikowicza, Kraków 2005, p. 143-198.

120 I. Skierska, op. cit., p. 220-221.

121 Statuty synodalne wieluńsko-kaliskie Mikołaja Trąby z r. 1420, ed. J. Fijałek, A. Vetulani, Kraków 1915-1920-1951, p. 38-39; W. Danielski, op. cit., p. 85.

122 W. Danielski, op. cit., p. 87-93.

123 Danielski, op. cit., p. 102-104; W. Schenk, op. cit., p. 84-86.

124 Danielski, op. cit., p. 106-108.

125 Pour un récapitulatif sur son culte en Bohême cf. J. Kadlec, Svatovojtěšská úcta v českých zemích [in:] Svatý Vojtěch. Sborník k mileniu, ed. J.V. Polc, Praha 1997, p. 42-75.

126 Cosmae Pragensis Chronica, II/5, p. 90-91.

127 Mentionné pour la première fois par Cosmae Pragensis Chronica (II/43, p. 148) vers 1090. 
latio $=$ Adalbert $/$ Vojtěch ${ }^{128}$. La vénération conjointe des deux saints est également documentée grâce à des pièces de monnaie des ducs de Bohême Bořivoj II et Vladislav $\mathrm{I}^{\mathrm{er}}$ des années 1118-1120, époque où ils partageaient le pouvoir. Chacun faisait certes frapper sa propre monnaie, mais au revers on retrouve la même image (sous différentes variantes) de saint Adalbert aux côtés de saint Venceslas ${ }^{129}$. Adalbert et Venceslas apparaissent dans la même position sur les sceaux du chapitre cathédral de Prague dès la deuxième moitié du XII ${ }^{\mathrm{e}}$ siècle ${ }^{130}$.

A cette époque, Adalbert devint aussi un personnage aidant le peuple tchèque dans son combat contre les ennemis. C'est celui qu'on appelle le Chanoine de Vyšehrad qui en parle la première fois dans la suite de la Chronique de Cosmas datant de 1126, à propos de la bataille de Chlumec (sous les Monts métallifères), au cours de laquelle

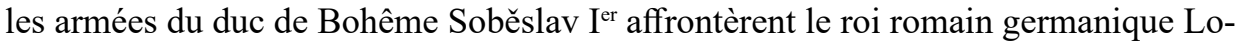
thaire III. Avant la bataille, le chapelain de Soběslav aurait découvert dans l'église de Vrbčany près de Kolín l'étendard de saint Adalbert qui fut ensuite attaché à la lance de saint Venceslas. La lance et l'étendard servirent de palladium pendant la bataille, grâce auquel les troupes tchèques écrasèrent l'armée germanique, et firent même prisonnier le roi Lothaire ${ }^{131}$. L'importance des patrons tchèques fut ensuite reconnue par les rois romains germaniques et les empereurs. Lorsque Frédéric Barberousse conféra en 1158 au duc de Bohême Vladislav II le statut de roi, il lui permit de porter la couronne royale lors des fêtes de Noël et des fêtes de saint Venceslas et saint Adalbert ${ }^{132}$.

En ce qui concerne les églises Saint-Adalbert, il y en avait moins en Bohême qu'en Pologne - on en compte seulement douze (et en Moravie, une seule à Slavičín) ${ }^{133}$. Parmi ces édifices (et outre la cathédrale de Prague), le plus important était l'église du monastère de Břevnov non loin de Prague. Selon la tradition de Břevnov documentée seulement à partir du XIII ${ }^{\mathrm{e}}$ siècle) - saint Adalbert en personne aurait fondé ce monastère avec le duc Boleslav II. Cet événement est censé avoir eu lieu en janvier 993, après son retour en Bohême du monastère Saints-Boniface-et-Alexis sur l'Aventin à Rome. Cette histoire n'est toutefois qu'une fiction tardive qui, au milieu du Moyen-âge, devait renforcer l'importance et la position du monastère de Břevnov comme plus ancien de Bohême. En réalité, c'est le duc Břetislav Ir qui fonda Břevnov, vraisemblablement après sa campagne polonaise de $1039^{134}$.

128 Cosmae Pragensis Chronica I/9, p. 19. A ce propos cf. L. Pavera, Dvě zlaté olivy v Kosmově kronice české [in:] Sv. Vojtěch v české a polské literatuře a v uměni / Postać św. Wojciecha w czeskiej i polskiej literaturze $i$ w sztuce, ed. L. Pavera, Opava 1999, p. 68-77.

129 P. Radoměrský, V. Ryneš, op. cit., p. 40-42

130 D. Stehlíková, Středověké pečeti se sv. Vojtěchem ve střední Evropě [in:] Svatý Vojtěch. Sbornik, ed. J.V. Polc, p. 131-139.

131 Kanovnik vyšehradský, p. 203-204.

${ }_{132}^{132},[\ldots]$ in festivitate videlicet sancti Venzelai et sancti Adelberti, eo quod illas solempnitates propter patronos suos maiori reverentia et celebritate tota Boemia veneretur". Codex diplomaticus et epistolaris regni Bohemiae 1, ed. G. Friedrich, Praha 1904-1907, No 180, p. 177.

133 Z. Boháč, Svatovojtěšské svatyně v Čechách a na Moravě [in:] Svatý Vojtěch. Sbornik, ed. J.V. Polc, p. 76-86.

${ }_{134}$ P. Kubín, Sind die ersten Mönche nach Böhmen aus dem Aventin gekommen? [in:] Römische Quartalschrift für Christliche Altertumskunde und Kirchengeschichte 108, 2013, p. 192-206. 
Dans la liturgie tchèque, la fête de saint Adalbert se célébrait le jour de la saint Georges, soit le 23 avril. Avec le temps, les deux fêtes furent toutefois scindées, celle de saint Georges étant reportée au jour suivant. Ceci est documenté pour la première fois dans un bréviaire du couvent de bénédictines situé à côté de l'église Saint-Georges au Château de Prague, datant de la deuxième moitié du XII ${ }^{\mathrm{e}}$ siècle $^{135}$. Néanmoins, en comparaison avec la fête de saint Venceslas, la création de textes à propos de saint Adalbert était relativement pauvre. Les premières séquences sur saint Adalbert - Hodierne lux diei a Laudes dicat omnis aetas - n'apparaissent qu'au XIV siècle $^{136}$. A cette époque, le culte tchèque de saint Adalbert avait déjà atteint son apogée, ce qu'illustraient notamment de nombreuses œuvres d'art où le saint était présenté aux côtés des saints patrons du pays ${ }^{137}$. La vénération de saint Adalbert était si forte que même les utraquistes ne la rejetèrent pas, comme en témoigne par exemple le tableau d'autel de Vliněves près Mělník (datant d'après 1520), où l'on voit maître Jan Hus servir d'assistant à Adalbert célébrant la messe ${ }^{138}$.

Outre la Pologne et la Bohême, le culte de saint Adalbert s'implanta également en Hongrie. Tout comme en Pologne, c'est à partir du saint qu'en l'an 1000 fut créée une province ecclésiastique indépendante, le siège métropolitain se trouvant à Esztergom. Dans le même temps, le duc de Hongrie Etienne obtint la couronne royale. D'après la légende de saint Etienne, rédigée par l'évêque Hartwig /BHL 7921/ dans les années 1112-1116, c'est à l'ancien ami et collaborateur d'Adalbert, Astrik-Anastasius qu'en revient le mérite ${ }^{139}$. Ce dernier - en tant qu'archevêque d'Esztergom - devint bientôt (au plus tard en 1007) le chef de l'Eglise hongroise ${ }^{140}$. La cathédrale d'Esztergom fut symboliquement consacrée à saint Adalbert justement ${ }^{141}$, son patron apparaissant ain-

135 Národní knihovna České republiky, VI E 13, p. III. Cf. M. Dragoun, Česká středověká kalendária. Mémoire soutenu au Département des sciences historiques auxiliaires à la Faculté des Lettres de l'Université Charles de Prague en 2000 (non-publié), p. 42, 55.

136 J. Kozina, M. Kozinová, Svatovojtěšské mešni officium na územi středověkých Čech [in:] Sv. Vojtěch v české a polské literatuře, p. 78-93.

137 Cf. par ex. F. Machilek, Zur Verehrung des hl. Wojciech-Adalbert in Böhmen, insbesondere im 14. Jahrhundert [in:] Święty Wojciech w tradycji i kulturze europejskiej, ed. K. Ś migiel, Gniezno 1992, p. 117-141; J. Royt, Kult a ikonografie sv. Vojtěcha v Čechách [in:] Tropami świętego Wojciecha, ed. Z. Kurnatowska, Poznań 1999, p. 374-387.

138 J. Pešina, Česká malba pozdní gotiky a renesance. Deskové maliřství 1450-1550, Praha 1950, p. 124, No 303-310; P. Kubín, J. Klípa, Deska z oltáře z Vliněvsi se sv. Vojtěchem a M. Janem Husem [in:] Jan Hus 1415/2015. Katalog výstavy, ed. Z. Vybíral, Tábor 2015, p. 247-248, No G6.5.2.

139 Legenda s. Stephani regis ab Hartvico episcopo conscripta, ed. E. Bartoniek [in:] Scriptores rerum Hungaricarum 2, ed. I. Szentpétery, Budapest 1938, chap. 9, p. 363-440, ici p. 412-414.

140 L'installation d'Astrik à Esztergom est confirmée par un écrit du synode de Francfort du 1er novembre 1007, où il est mentionné comme „Anastasius Ungrorum archiepiscopus interfui et subscripsi”, Monumenta Germaniae Historica. Diplomatum regum et imperatorum Germaniae 3: Henrici II et Arduini diplomata, ed. H. Bresslau, H. Bloch, R. Holtzmann, Hannover 1900-1903, No 143, p. 172.

${ }^{141}$ Le patrocinium de saint Adalbert pour la cathédrale d'Esztergom n'est confirmé qu'à partir de 1157, mais il ne fait aucun doute qu'il soit celui d'origine. Cf. Codex diplomaticus et epistolaris Slovaciae 1, ed. R. Marsina, Bratislava 1971, No 83, p. 81. A ce propos cf. F. Oslanský, Kult sv. Vojtecha a Slovensko v stredověku [in:] J. Nemeš, R. Kožiak et al., Svätý Vojtech - svätec, doba a kult, Bratislava 2011, p. 89-109, ici p. 92. 
si plus tard sur les sceaux archépiscopaux et capitulaires ${ }^{142}$. Outre la cathédrale d'Esztergom, on trouvait dans la Hongrie médiévale quinze autres églises Saint-Adalbert, dont cinq sur le territoire de l'actuelle Slovaquie ${ }^{143}$. Le culte d'Adalbert en Hongrie trouve sa source dans le récit de la légende majeure de saint Etienne /BHL 7918/ (rédigée avant 1083), selon laquelle le premier roi de Hongrie, encore nommé prince Vajk, aurait été baptisé par saint Adalbert en personne, lequel lui aurait alors donné le nom d'Etienne ${ }^{144}$. Qu'il se fût agi d'un baptême ou d'une confirmation, comme le pensent certains historiens hongrois et slovaques, le lien d'Adalbert avec le principal patron hongrois eut une importance capitale pour son culte en Hongrie ${ }^{145}$. Adalbert fut principalement vénéré dans le diocèse d'Esztergom, c'est-à-dire sur le territoire de l'actuelle Slovaquie, comme en témoignent par exemple la statue en pierre du saint dans l'église Notre-Dame de Banská Bystrica, datant du début du XVI siècle, ou le tableau représentant Adalbert sur une aile d'un autel, datant des années 14701478, dans l'église Saint-Martin du chapitre de Spišs" ${ }^{16}$.

Des textes liés à la fête de saint Adalbert apparaissent dans les livres liturgiques hongrois tout au long du Moyen-âge. D'abord dans le Codex de Nitra, qui vit le jour en 1083, évangéliaire destiné au monastère bénédictin de Hronský Beňadik. Plus jeune, datant de la première moitié du XII ${ }^{\mathrm{e}}$ siècle, on a également l'antiphonaire de Albe Royale (Székesfehérvár) où Adalbert possède sa propre antienne ${ }^{147}$. Dans la liturgie hongroise, Adalbert avait deux fêtes : celle de son martyre et celle de sa translation. La première se célébrait donc comme ailleurs le 23 avril. On chantait à cette occasion l'office spécial $O$ immarcescibilis rosa. La translation, elle, était célébrée le 6 novembre seulement et l'on entonnait alors l'office Ad festa preciosi ${ }^{148}$.

Dès le XIII ${ }^{e}$ siècle, le culte de saint Adalbert commence à se diffuser dans des contrées lointaines. Quand, en 1255, le roi de Bohême Přemysl Otakar II fonda en Prusse la ville de Königsberg (aujourd'hui Kaliningrad), à l'occasion d'une croisade, il y fit construire une cathédrale Saint-Adalbert pour servir d'église épiscopale au diocèse de Samland récemment créé ${ }^{149}$. A la fin du Moyen-âge, aux XIV et XV ${ }^{\mathrm{e}}$

142 F. Oslanský, op. cit.

143 R. Marsina, Sv. Vojtěch a Ostrihom [in:] J. Nemeš, R. Kožiak et al., Svätý Vojtech - svätec, p. 11-22, ici p. 18.

144 „Hunc Deo dilectus Adalbertus episcopus crismali baptismate secundum credulitatis sue veritatem intixit et suceptor eius fuit. Nomen sibi impositum est Stephanus [...]", Legenda maior s. Stephani regis, ed. E. Bartoniek, Scriptores rerum Hungaricarum 2, ed. I. Szentpétery, Budapest 1938, p. 377-392, ici p. 380.

145 A ce propos cf. B. Pinterová, Sv. Vojtech na dvore kniežat’a Gejzu v mad’arskej a slovenskej historiografii [in:] J. Nemeš, R. Kožiak et al., Svätý Vojtech - svätec, p. 171-176; I. Nagy, Obraz sv. Vojtecha v modernej mad'arskej historiografii [in:] Svätý Vojtech - svätec, p. 177-186.

146 F. Oslanský, op. cit., p. 105-108.

147 L. Némethy, Úcta sv. Vojtěcha v Uhrách, „Časopis katolického duchovenstva” 1897, 38, p. 232-239, 300-304, 372-375, 431-436, 493-497, 530-539; R. Marsina, op. cit.

148 E. Veselovská, Kult sv. Vojtecha vostrihomskej liturgickej tradícii [in:] J. Nemeš, R. Kožiak et al., Svätý Vojtech - svätec, p. 110-139.

149 Le chroniqueur de Charles IV Přibík Pulkava z Radenína en parle dans la toute première version de sa chronique datant des années 1364-1374: „Construens /rex Prziemisl/ nichilominus ibidem /in Kunigspeg/ ecclesiam kathedralem in honore sancti Adalberti martiris, patroni Boemie, secundi quondam 
siècles, le culte de saint Adalbert fit son retour en Occident. Sa fête apparait - d'après des recherches aléatoires - dans des livres de Rome, Paris, Metz, Maastricht, Liège, Eichstätt, Passau ${ }^{150}$. Il est même allé jusque dans le Nord, plus précisément à Lund, au Danemark (aujourd'hui en Suède) ${ }^{151}$.

\section{CONCLUSION}

Il existe plusieurs différences essentielles entre le culte de saint Venceslas et celui d'Adalbert. Tandis que Venceslas fut proclamé saint seulement après la création de l'évêché de Prague (973), soit plusieurs dizaines d'années après sa mort, Adalbert fut canonisé pratiquement tout de suite après son martyre, sur ordre de Boleslas le Vaillant et de l'évêque de Poznań Unger durant l'été 997. Le culte d'Adalbert, contrairement à celui de Venceslas, commença sur les chapeaux de roue et fit l'objet de grandes ambitions car l'empereur Otton III songeait à en faire un des saints patrons de l'empire. Malheureusement, en raison de la mort prématurée d'Otton III, ce projet ne fut pas mené à terme et il n'en resta que des bribes sous forme d'églises disséminées dans les lieux importants de l'empire. Le culte d'Adalbert s'implanta d'autant plus fortement en Pologne où en l'an 1000, fut créée sur ses bases l'organisation ecclésiastique de Pologne, avec sa métropole à Gniezno. De la même façon et à la même époque, Adalbert devint en Hongrie le symbole de la structure ecclésiastique récemment créée, dont le siège archiépiscopal se trouvait à Esztergom. En Bohême, en raison de l'inimitié originelle des Tchèques, Adalbert commença à être vénéré avec un certain retard, soit après 1039 , date à laquelle ses reliques furent rapportées de Gniezno dans la cathédrale de Prague. Bien qu'il ait été mis aux côtés de saint Venceslas, il n'atteignit jamais son importance. Au contraire, Venceslas devint, dès le courant du $\mathrm{XI}^{\mathrm{e}}$ siècle, le saint patron principal de l'Etat tchèque, souverain éternel de son pays. Son culte en Bohême dépassait largement la vénération vouée aux autres saints. Au début, il se diffusa également en Pologne. A Cracovie, l'église Saint-Venceslas fut même élevée au rang de cathédrale, mais son culte n'atteignit jamais l'importance de celui d'Adalbert. Dans l'empire, tout comme en Hongrie, le culte de saint Venceslas n'apparut que de façon marginale.

\footnotetext{
Pragensis episcopi, qui coronam martirii dudum a Prutenis suscepit, nominans illius ecclesie diocesim Sambiensem”. Kronika Pulkavova, FRB 5, ed. J. Emler, J. Gebauer, Praha 1893, p. 1-326, ici p. 147. A propos de la création du diocèse, cf. M. Glauert, Bistum Samland [in:] Die Bistümer des Heiligen Römischen Reiches 1, ed. E. Gatz, Freiburg i. Br. 2003, p. 655-662.

${ }_{150}$ P. Kubín, Svátky českých světců ve středověkých rukopisech pařižské Bibliothèque nationale de France; P. Kubín, Svátky českých světců ve středověkých rukopisech francouzských knihoven...

151 J. Nalepa, Ślady kultu świętego Wojciecha w poludniowej Skandynawii, „Roczniki Historyczne” 1996, 62, p. 143-149.
} 


\title{
BIBLIOGRAPHIE
}

\author{
Manuscrits
}

Biblioteca Capitolare Verona, Cod. LXXXVII.

Národní knihovna České republiky, VI E 13.

\section{Sources}

Annales et notae Babenbergenses, Monumenta Germaniae Historica, Scriptores 17, ed. Ph. Jaffé, Hannover 1861 p. 634-642.

Annales Quedliburgenses, Monumenta Germaniae Historica, Scriptores 3, ed. G.H. Pertz, Hannover 1839, p. 72-90.

Annalista Saxo, ed. K. Nass, Monumenta Germaniae Historica, Scriptores 37, Hannover 2006.

Codex diplomaticus et epistolaris regni Bohemiae 1, ed. G. Friedrich, Praha 1904-1907.

Codex diplomaticus et epistolaris Slovaciae 1, ed. R. Marsina, Bratislava 1971.

Cosmae Pragensis Chronica Boemorum, Monumenta Germaniae Historica, Scriptores rerum Germanicarum, Nova Series 2, ed. B. Bretholz, Berlin 1923.

De s. Adalberto, episcopo Pragensi, ed. M. Perlbach, Monumenta Germaniae Historica, Scriptores 15,2, Hannover 1886, p. 1177-1184.

Die Wenzelslegende „, Oriente iam sole”/Die erste Rezension/, ed. J. Pekař [in:] J. Pekař, Die Wenzels- und Ludmila- Legenden und die Echtheit Christians, Praha 1906, p. 409430.

Druhá staroslovanská legenda o sv. Václavu, ed. J. Vašica [in:] Sborník staroslovanských památek o sv. Václavu a sv. Lidmile, ed. J. Vajs, Praha 1929, p. 71-135.

Galli Anonymi cronicae et gesta ducum sive principum Polonorum, Monumenta Poloniae Historica, Nova Series 2, ed. K. Maleczyński, Kraków 1952.

Kanovnik vyšehradský, Fontes rerum Bohemicarum 2, ed. J. Emler, Praha 1874, p. 201-237.

Kodeks dyplomatyczny katedry krakowskiej św. Wacława 1, ed. F. Piekosiński, Kraków 1874.

Kristiánova legenda / Legenda Christiani, ed. J. Ludvíkovský, Praha 1978.

Kronika Pulkavova, Fontes rerum Bohemicarum 5, ed. J. Emler, J. Gebauer, Praha 1893, p. $1-326$.

Laurentius, monachus Casinensis, archiepiscopus Amalfitanus, Opera, Monumenta Germaniae Historica, Quellen zur Geistesgeschichte des Mittelalters 7, ed. F. Newton, Weimar 1973.

Legenda maior s. Stephani regis, ed. E. Bartoniek, Scriptores rerum Hungaricarum 2, ed. I. Szentpétery, Budapest 1938, p. 377-392.

Legenda s. Stephani regis ab Hartvico episcopo conscripta, ed. E. Bartoniek, Scriptores rerum Hungaricarum 2, ed. I. Szentpétery, Budapest 1938, p. 363-440.

Monumenta Germaniae Historica. Diplomatum regum et imperatorum Germaniae 3: Henrici II et Arduini diplomata, ed. H. Bresslau, H. Bloch, R. Holtzmann, Hannover 1900-1903. 
Mnich sázavský, Fontes rerum Bohemicarum 2, ed. J. Emler, Praha 1874, p. 238-269.

Passio Adalberti episcopi martyris, ed. G. Waitz, Monumenta Germaniae Historica. Scriptores $15 / 2$, Hannover 1888 , p. 705-708.

Pražské synody a koncily předhusitské doby, ed. J.V. Polc, Z. Hledíková, Praha 2002.

Př́běhy krále Přemysla Otakara II., Fontes rerum Bohemicarum 2, ed. J. Emler, Praha 1874, p. 308-335.

Rocznik małopolski, ed. A. Bielowski, Monumenta Poloniae Historica 3, Lwów 1878, p. 135-202.

Rocznik Traski i krakowski, ed. A. Bielowski, Monumenta Poloniae Historica 2, Lwów 1872, p. 826-861.

S. Adalberti Pragensis, episcopi et martyris Vita prior, Monumenta Poloniae Historica, Series Nova 4/1, ed. J. Karwasińska, Warszawa 1962.

S. Adalberti Pragensis episcopi et martyris Vita altera auctore Brunone Querfurtensi, Monumenta Poloniae Historica, Series Nova 4/2, ed. J. Karwasińska, Warszawa 1969.

Sborník staroslovanských literárních památek o sv. Václavu a sv. Ludmile, ed. J. Vajs, Praha 1929.

Spisy dawne skarbca i biblioteki kapitulnej krakowskiej, ed. A. Bielowski, Monumenta Poloniae Historica 1, Lwów 1864, p. 376-378.

Statuta capitolorum generalium ordinis cisterciensis ab anno 1116 ad annum 1786 I, ed. J. Canivez, Louvain 1933.

Statuty synodalne krakowskie Zbigniewa Oleśnickiego (1436, 1446), ed. S. Zachorowski, Kraków 1915.

Statuty synodalne wieluńsko-kaliskie Mikołaja Trąby z r. 1420, ed J. Fijałek, A. Vetulani, Kraków 1915-1920-1951.

Vita quinque fratrum eremitarum seu Vita vel Passio Benedicti et Iohannis sociorumque suorum auctore Brunone Querfurtensi, Monumenta Poloniae Historica, Series Nova 4/3, ed. J. Karwasińska, Warszawa 1973.

Vita sancti Wenceslai incipiens verbis „,Ut annuncietur”, ed. A. Podlaha, Praha 1917.

Widukindi monachi Corbeiensis Rerum gestarum Saxonicarum libri tres, ed. P. Hirsch, H.-E. Lohmann, Monumenta Germaniae Historica, Scriptores Rerum Germanicarum in usum scholarum 60, Hannover 1935.

Život sv. Václava, Fontes rerum Bohemicarum 1, ed. J. Emler, Praha 1873, p. 183-190.

\section{Études}

Barciak A., W sprawie kultu św. Wacława na Ślasku w XIII w. [in:] idem, Między Polska a Czechami. Śląsk i jego mieszkańcy w źródtach czeskich doby średniowiecza, Wrocław 2012, p. 177-188.

Bartlová M., Kř́dla retáblu z Roudník [in:] Umění české reformace (1380-1620), ed. K. Horníčková, M. Šroněk, Praha 2010.

Blaschka A., Die St. Wenzelslegende Kaiser Karls IV., Einleitung, Texte, Praha 1934.

Boháč Z., Kotázce zasvěcení kostelů v oboru historické geografie, „Československý časopis historický" 1968, 16, p. 571-584.

Boháč Z., Patrocinia kostelů při nejstarších klášterech a kapitulách v českých zemích, „Historická geografie" 1970, 5, p. 51-76. 
Boháč Z., Patrocinia románských kosteli̊ v Čechách, „Historická geografie” 1972, 8, p. 31-52.

Boháč Z., Svatovojtěšské svatyně v Čechách a na Moravě [in:] Svatý Vojtěch. Sborník k mileniu, ed. J. V. Polc, Praha 1997, p. 76-86.

Čarek J., O pečetěch českých knižat a králi̊ z rodu Přemyslova, Sborník příspěvků k dějinám hl. m. Prahy 8, 1938, p. 1-56.

Chotěbor P., Kostel Panny Marie v Sulzbachu v souvislostech karlovského umění, „Umění” 2003, 51, p. 506-509.

Chudziakowa J., Z badań nad architektura sakralna $w$ Trzemesznie (z lat 1987-1988), „Acta Universitatis Nicolai Copernici, Archeologia 20 - Nauki Humanistyczno-Społeczne" 1992, 244, p. 9-20.

Cibulka J., Václavova rotunda svatého Vita [in:] Svatováclavský sborník I - Kniže Václav Svatý a jeho doba, ed. K. Stloukal, J. Kapras, K. Guth, A. Novák, Praha 1934, p. 230-685.

Clausen P.C., Der Wenzelalter in Alt St. Peter. Heiligenverehrung, Kunst und Politik unter Karl IV., „Zeitschrift für Kunstgeschichte” 1980, 43, p. 280-299.

Čermák V., Ke kořenům církevněslovanského písemnictví kláštera Na Slovanech [in:] Karel IV. a Emauzy. Liturgie, text a obraz, ed. K. Kubínová, Praha 2017, p. 16-29.

Danielski W., Z dziejów kultu liturgicznego św. Wojciecha na ziemach polskich. Święta ku czci św. Wojciecha, „Roczniki Teologiczno-Kanoniczne” 1967, 14, p. 83-111.

David P., Les bénédictins et l'ordre de Cluny dans la Pologne médiévale, Paris 1939.

Doležalová E., Svěcenci pražské diecéze 1395-1416, Praha 2010.

Dragoun M., Česká středověká kalendária. Mémoire soutenu au Département des sciences historiques auxiliaires à la Faculté des Lettres de l'Université Charles de Prague en 2000 (non-publié).

Dunin-Wąsowicz T., Kulty świętych $w$ Polsce $w$ X wieku [in:] Polska $w$ świecie. Szkice z dziejów kultury polskiej, Warszawa 1972, p. 61-77.

Europas Mitte um 1000. Beiträge zur Geschichte, Kunst und Archäologie, ed. A. Wieczorek, H.-M. Hinz, Stuttgart 2000.

Fried J., Gnesen-Aachen-Rom. Otto III. und der Kult des hl. Adalbert. Beobachtungen zum älteren Adalbertsleben [in:] Polen und Deutschland vor 1000 Jahren. Die Berliner Tagung über den „Akt von Gnesen“, ed. M. Borgolte, Berlin 2002, p. 235-279.

Giesztor A., Politische Heilige im hochmittelalterlichen Polen und Böhmen [in:] Politik und Heiligenverehrung im Hochmittelalter, ed. Jürgen Petersohn, Sigmaringen 1994, p. 325-341.

Glauert M., Bistum Samland [in:] Die Bistümer des Heiligen Römischen Reiches I, ed. E. Gatz, Freiburg i. Br. 2003, p. 655-662.

Glushko E., Medieval Challenges Modern. Legenda Christiani and Its Author in Czech Historiography, Saarbrücken 2008.

Godula R., ,,Onego czasu, gdy święty Wojciech...”, czyli rzecz o mityzacji Sławnikowicza, Kraków 2005.

Graus F., Böhmen zwischen Bayern und Sachsen, „Historica” 1969, 17, p. 5-42.

Graus F., Die Heilige als Schlachtenhelfer. Zur Nationalisierung einer Wundererzählung in der mittelalterlichen Chronistik [in:] Festschrift für Helmut Beumann, ed. K.-U. Jäschke, R. Wenskus, Sigmaringen 1977, p. 330-348.

Graus F., Kirchliche und heidnische (magische) Komponenten der Stellung der Přemysliden. Přmyslidensage und St. Wenzelsideologie [in:] Siedlung und Verfassung Böhmens in der Frühzeit, ed. F. Graus, H. Ludat, Wiesbaden 1967, p. 148-161. 
Graus F., St. Adalbert und St. Wenzel. Zur Funktion der mittelalterlichen Heiligenverehrung in Böhmen [in:] Europa Slavica - Europa Orientalis. Festschrift für Herbert Ludat zum 70. Geburtstag, ed. K-D. Grothusen, K. Zernack, Berlin 1980, p. 205-231.

Hilger H. P., Der Altar des Hl. Wenzel im Dom zu Aachen, „Aachener Kunstblätter” 1973, 44, p. 211-232.

Hlaváček I., Przyczynek do czesko-polskich kontaktów ksiązkowych za panowania Przemyślidów, „Archiwa, Biblioteki i Muzea Kościelne” 1976, 33, p. 313-328.

Hledíková Z., Postava svatého Václava ve 14. a 15. století [in:] Svatý Václav, ed. P. Kubín, Praha 2010, p. 239-252.

Hledíková Z., Die Prager Erzbischöfe als ständige päpstliche Legaten. Ein Beitrag zur Kirchenpolitik Karls IV. [in:] Regensburg und Böhmen, ed. G. Schwaiger, J. Staber, Regensburg 1972, p. 221-256.

Hoffmann J., Vita Adalberti. Früheste Textüberlieferungen der Lebensgeschichte Adalberts von Prag, Essen 2005, p. 78-121.

Holinka R., Svatý Vojtěch, Brno 1947.

Janiak T., Problematyka wczesnych faz kościoła katedralnego w Gnieźnie [in:] Poczatki architektury monumentalnej w Polsce, ed. T. Janiak, D. Stryniak, Gniezno 2004, p. $85-130$.

Józefowiczówna K., Trzemeszno. Klasztor św. Wojciecha $w$ dwóch pierwszych wiekach istnienia, Warszawa-Poznań 1978.

Kaczmarek R., Umění ve Slezsku, uměni v českých zemích a lucemburský mecenát: Mezi svizelným dédictvím a bezvýhradným přijetím? [in:] Slezsko, perla v české koruně. Historie - kultura - umění, ed. M. Kapustka, J. Klípa, A. Kozieł, P. Oszczanowski, V. Vlnas, Praha 2007, p. 115-147.

Kadlec J., Svatovojtěšská úcta v českých zemích [in:] Svatý Vojtěch. Sborník k mileniu, ed. J.V. Polc, Praha 1997, p. 42-75.

Kahsnitz R., Sakramentar des hl. Wolfgang [in:] Otto der Grosse. Magdeburg und Europa. Ausstellungskatalog, ed. M. Puhle, Mainz 2001, p. 275-278.

Kalhous D., Anatomy of a Duchy. The Political and Ecclesiastical Structures of Early Přemyslid Bohemia, Leiden-Boston 2012.

Kalhous D., Legenda Christiani and Modern Historiography, Leiden-Boston 2015.

Kalousek J., Kalendář českého pưvodu z prostředka 12. století, „Časopis Musea Království českého" 1902, 76, p. 159-165.

Karwasińska J., Wojciech-Adalbert [in:] Hagiografia Polska, Stownik bio-bibliograficzny 2, Poznań-Warszawa-Lublin 1972, p. 572-589.

Kniewald D., Zagrebački liturgijski kodeksi XI. - XV. stoljeća, Zagreb 1940.

Kozina J., Kozinová M., Svatovojtěšské mešní officium na území středověkých Čech [in:] Sv. Vojtěch v české a polské literatuře a v uměni/Postać św. Wojciecha $w$ czeskiej i polskiej literaturze $i$ w sztuce, ed. L. Pavera, Opava 1999, p. 78-93.

Kozłowska-Budkowa Z., Który Bolesław? [in:] Prace z dziejów Polski feudalnej ofiarowane Romanowi Grodeckiemu, ed. Z. Kozłowska-Budkowa et al., Warszawa 1960, p. 81-89.

Krásl F., Ježek J., Sv. Vojtěch, druhý biskup pražský, jeho klášter i úcta u lidu, Praha 1898.

Kubín P., Klípa J., Deska z oltáre z Vliněvsi se sv. Vojtěchem a M. Janem Husem [in:] Jan Hus 1415/2015. Katalog výstavy, ed. Z. Vybíral, Tábor 2015, p. 247-248, No G6.5.2.

Kubín P., Čeští světci ve středověkých rukopisech Durynska (Jena-Gotha-Erfurt-Výmar), „Acta Universitatis Carolinae - Philosophica et historica 1995 (= Z pomocných věd historických 12)", p. 9-71. 
Kubín P., Sedm přemyslovských kulti̊, Praha 2011.

Kubín P., Sind die ersten Mönche nach Böhmen aus dem Aventin gekommen? [in:] Römische Quartalschrift für Christliche Altertumskunde und Kirchengeschichte 108, 2013, p. 192-206.

Kubín P., Svátky českých světců ve středověkých rukopisech pařrižské Bibliothèque nationale de France, Sborník. Katolické teologické fakulty 4, ed. M. Mikulicová, P. Kubín, Praha 2002, p. 344-422.

Kubín P., Svátky českých světců ve středověkých rukopisech francouzských knihoven $a$,,kanonizační akta” sv. Vojtěcha v Pařiži, Sborník Katolické teologické fakulty 7, ed. P. Kubín, M. Mikulicová, D. Svoboda, Praha 2005, p. 270-284.

Kubín P., Svatorečení biskupa Vojtěcha [in:] Kościót $w$ monarchiach Przemyślidów i Piastów, ed. J. Dobosz, Poznań 2009, p. 99-103.

Kubínová K., Imitatio Romae. Karel IV. a Řim, Praha 2006.

Kürbis B., O życiu religijnym w Polsce X-XII wieku [in:] Pogranicza i konteksty literatury polskiego średniowiecza, ed. T. Michałowska, Wrocław 1989, p. 7-55.

Kurnatowska Z., Die Christianisierung Polens im Lichte der archäologischen Quellen [in:] Europas Mitte um 1000. Beiträge zur Geschichte, Kunst und Archäologie, ed. A. Wieczorek, H.-M. Hinz, Stuttgart 2000, p. 490-493.

Kuthan J., K šiření kultu svatého Václava za hranice Čech a Moravy v době Přemyslovcu a Lucemburkủ [in:] Svatý Václav, ed. P. Kubín, Praha 2010, p. 221-238.

Labuda G., Kanonizacja świętego Wojciecha, „Kwartalnik Historyczny” 2005, 112, No. 3, p. $33-40$.

Labuda G., Mieszko II, król Polski (1025-1034). Czasy przełomu w dziejach państwa, Kraków 1992.

Labuda G., Święty Wojciech. Biskup - mȩczennik. Patron Polski, Czech i Wȩgier, Wrocław 2000.

Leśniewska D., Kodeks Gertrudy. Stan i perspektywy badań, „Roczniki Historyczne” 1995, 61, p. 141-170.

Ludvíkovský J., Nově zjištěný rukopis legendy Crescente fide a jeho význam pro datování Kristiána, „Listy filologické” 1958, 6, p. 56-68.

Ludvíkovský J., Václavská legenda XIII. století „,Ut annuncietur“, její poměr k legendě Oriente a otázka autorství, „Listy filologické” 1955, 3, p. 196-205.

Lutovský M., Bratrovrah a tviorce státu. Život a doba knižete Boleslava I., Praha 2006.

Machilek F., Privatfrömmigkeit und Staatsfrömmigkeit [in:] Kaiser Karl IV. Staatsmann und Mäzen, ed. F. Seibt, München 1978, p. 87-101.

Machilek F., Zur Verehrung des hl. Wojciech-Adalbert in Böhmen, insbesondere im 14. Jahrhundert [in:] Święty Wojciech $w$ tradycji i kulturze europejskiej, ed. K. Śmigiel, Gniezno 1992, p. 117-141.

Marsina R., Sv. Vojtěch a Ostrihom [in:] J. Nemeš, R. Kožiak et al., Svätý Vojtech-svätec, doba a kult, Bratislava 2011, p. 11-22.

Maříková-Kubková J., Herichová I., Archeologickýatlas Pražského hradu 1 - Katedrála sv. Vita - Vikářská ulice (= Castrum Pragense 10), Praha 2009.

Matla-Kozłowska M., Pierwsi Przemyślidzi i ich państwo (od X do połowy XI wieku). Ekspansja terytorialna i jej polityczne uwarunkowania, Poznań 2008.

Merhautová A., Třeštík D., Ideové proudy v českém uměni 12. století, Praha 1985.

Michałowski R., Princeps fundator. Studium z dziejów kultury politycznej w Polsce X-XIII wieku, Warszawa 1993. 
Michałowski R., Zjazd Gnieźnieński. Religijne przestanki powstania arcybiskupstwa gnieźnieńskiego, Wrocław 2005.

Mudra A., Královské atributy ve středověké ikonografii svatého Václava [in:] Svatý Václav, ed. P. Kubín, Praha 2010, p. 329-344.

Nagy I., Obraz sv. Vojtecha v modernej mad'arskej historiografii [in:] J. Nemeš, R. Kožiak et al., Svätý Vojtech - svätec, doba a kult, Bratislava 2011, p. 177-186.

Nalepa J., Ślady kultu świętego Wojciecha w południowej Skandynawii, „Roczniki Historyczne" 1996, 62, p. 143-149.

Nastalska J., Bonus et iustus. Święty Wactaw w 1. starosłowiańskiej legendzie. Se nyny sbys't [in:] Peregrinatio ad veritatem. Studia ofiarowane profesor Aleksandrze Witkowskiej OSU z okazji 40-lecia pracy naukowej, ed. U. Borkowka, Cz. Deptuła, R. Knapiński, Z. Piłat, E. Wiśniowski, Lublin 2004, p. 325-344.

Nastalska-Wiśnicka J., Rex martyr. Studium źródłoznawcze nad legenda hagiograficzna św. Wactawa (X-XIV w.), Lublin 2010.

Němec R., Caroli IV. Imperatoris Romani Fundatio: Kostel kláštera Celestinů na Ojvíně u Žitavy, „Průzkumy památek” 2004, 11, p. 3-52.

Némethy L., Úcta sv. Vojtěcha v Uhrách, „Časopis katolického duchovenstva” 1897, 38, p. 232-239, 300-304, 372-375, 431-436, 493-497, 530-539.

Oslanský F., Kult sv. Vojtecha a Slovensko v stredověku [in:] J. Nemeš, R. Kožiak et al., Svätý Vojtech - svätec, doba a kult, Bratislava 2011, p. 89-109.

Otavský K., Svatováclavská koruna a její funkce [in:] Svatý Václav, ed. P. Kubín, Praha 2010, p. 253-266.

Ottová M., Zobrazení svatého Václava za vlády Jagellonců v českých zemích [in:] Svatý Václav, ed. P. Kubín, Praha 2010, p. 345-362.

Ożóg K., 966. Chrzest Polski, Kraków 2016.

Paszkiewicz B., Svatý biskup na polských středověkých mincích [in:] Po stopách sv. Vojtěcha (= Antiqua Cuthna 3), ed. J. K. Kroupa, L. Polanský, J. Sláma, V. Vaněk, Praha 2014, p. 141-159.

Pavera L., Dvě zlaté olivy v Kosmově kronice české [in:] Sv. Vojtěch v české a polské literatuře a v uměni / Postać św. Wojciecha $w$ czeskiej i polskiej literaturze $i w$ sztuce, ed. L. Pavera, Opava 1999, p. 68-77.

Pešina J., Česká malba pozdní gotiky a renesance. Deskové maliřství 1450-1550, Praha 1950.

Pianowski Z., Architektura monumentalna wczesnośredniowiecznego Krakowa [in:] Kraków w chrześcijańskiej Europie X-XIII w., ed. M. Niezabitowski, Kraków 2006, p. $163-219$.

Pianowski Z., Krakau (Kraków) [in:] Europas Mitte um 1000. Beiträge zur Geschichte, Kunst und Archäologie, ed. A. Wieczorek, H.-M. Hinz, Stuttgart 2000, p. 479-482.

Pinterová B., Sv. Vojtech na dvore kniežat'a Gejzu v mad'arskej a slovenskej historiografii [in:] J. Nemeš, R. Kožiak et al., Svätý Vojtech - svätec, doba a kult, Bratislava 2011, p. 171-176.

Pobóg-Lenartowicz A., Najstaršie Životy sv. Vojtecha. Vitae s. Adalberti [in:] J. Nemeš, R. Kožiak et al., Svätý Vojtech - svätec, doba a kult, Bratislava 2011, p. 33-54.

Radoměrský P., Ryneš V., Společná úcta sv. Václava a sv. Vojtěcha zvláště na českých mincich a její historický význam, „Numismatické listy” 1958, 13, p. 35-48.

Radwański K., Kraków przedlokacyjny. Rozwój przestrzenny, Kraków 1975.

Rajman J., Średniowieczne patrocinia krakowskie, Kraków 2002. 
Reisch Chr., Geschichte des Klosters und der Kirche St. Dorothea in Breslau, Wrocław 1908.

Rettich E., Klapproth R., Ewald G., Alte Meister. Staatsgalerie Stuttgart. Ausstellungskatalog, Stuttgart 1992.

Royt J., Ikonografie svatého Václava ve středověku [in:] Svatý Václav, ed. P. Kubín, Praha 2010, p. 301-327.

Royt J., Kult a ikonografie sv. Vojtěcha v Čechách [in:] Tropami świętego Wojciecha, ed. Z. Kurnatowska, Poznań 1999, p. 374-387.

Rożnowska-Sadraei A., Pater Patriae. The Cult of Saint Stanislaus and the Patronage of Polish Kings 1200-1455, Kraków 2008.

Ryneš V., Hásková J., K počátkům svatováclavského motivu na českých denárech, „Numismatické listy" 1967, 22, p. 145-152.

Sauerland H.V., Haseloff A., Der Psalter Erzbischof Egberts von Trier, Codex Gertrudianus in Cividale, Trier 1901.

Schenk W., Kult świętych w Polsce, „Roczniki Teologiczno-Kanoniczne” 1966, 13, p. 77 102.

Schwerdel-Schmidt H., Der heilige Wenzel [in:] Zeit und Ewigkeit. 128 Tage in St. Marienstern, Ausstellungskatalog, ed. J. Oexle, Halle a. d. Saale 1998, p. 261-262.

Siede I., Psalter Erzbischof Egberts von Trier [in:] Heiliges Römisches Reich deutscher Nation 962 bis 1806. Vom Otto dem Grossen bis zum Ausgang des Mittelalters, Ausstellungskatalog, ed. M. Puhle, C.-P. Hasse, Dresden 2006, p. 98.

Skierska I., Sabbatha sanctifices. Dzień święty w średniowiecznej Polsce, Warszawa 2008.

Sláma J., Kniže sv. Václav [in:] J. Sláma et al., Střední Čechy, kolébka národních patronů, sv. Ludmila, sv. Václav, sv. Vojtěch, sv. Prokop, Kladno 2015, p. 89-114.

Sobeczko H., Kult liturgiczny św. Wacława na Ślasku w świetle średniowiecznych rękopisów liturgicznych, „Roczniki Teologiczno-Kanoniczne” 1967, 14, p. 55-81.

Stehlíková D., Středověké pečeti se sv. Vojtěchem ve střední Evropě [in:] Svatý Vojtěch. Sbornik k mileniu, ed. J.V. Polc, Praha 1997, p. 131-139.

Stejskal F., Svatý Václav. Jeho život a úcta, Praha 1925.

Strzelczyk J., Das Treffen in Gnesen und die Gründung des Erzbistums Gnesen [in:] Europas Mitte um 1000. Beiträge zur Geschichte, Kunst und Archäologie, ed. A. Wieczorek, H.-M. Hinz, Stuttgart 2000, p. 494-497.

Suchodolski S., Kult svatého Václava a svatého Vojtěcha prizmatem raně středověkých polských mincí, „Numismatický sborník” 2005, 20, p. 29-42.

Svatý Václav, ed. P. Kubín, Praha 2010.

Šmahel F., Úcta ke svatému Václavu v husitských Čechách [in:] Svatý Václav, ed. P. Kubín, Praha 2010, p. 281-299.

Třeštík D., Idea státu a národa [in:] Přemyslovci. Budování českého státu, ed. P. Sommer, D. Třeštík, J. Žemlička, Praha 2009, p. 272-286.

Třeštík D., Miscellanea zu den St. Wenzelslegenden 2: Laurentius aus Monte Cassino und Laurentius aus Amalfi, „Mediaevalia Bohemica” 1969, 1, p. 73-92.

Třeštík D., Počátky Přemyslovců. Vstup Čechů do dějin /530-935/, Praha 1997.

Turek R., Svatý Václav [in:] Bohemia sancta. Životopisy českých světců a př́tel božich, ed. J. Kadlec, Praha 1989, p. 53-71.

Uhlíř Z., Literárni prameny svatováclavského kultu a úcty ve vrcholném a pozdním středověku, Praha 1996, p. 18-34.

Uhlirz M., Jahrbücher des Deutschen Reiches unter Otto II. und Otto III., Bd. 2: Otto III. 983-1002, Berlin 1954. 
Vajs J., Nejstarši breviár chrvatsko-hlaholský, Praha 1910.

Vaníček V., Svatý Václav. Panovník a světec v raném středověku, Praha-Litomyšl 2014.

Veselovská E., Kult sv. Vojtecha v ostrihomskej liturgickej tradicii [in:] J. Nemeš, R. Kožiak et al., Svätý Vojtech - svätec, doba a kult, Bratislava 2011, p. 110-139.

Voigt H.G., Adalbert von Prag. Ein Beitrag zur Geschichte der Kirche und Mönchtums im zehnten Jahrhundert, Weltend-Berlin 1898.

Wąsowicz H., Kalendarz ksiąg liturgicznych Krakowa do połowy 16. wieku. Studium chronologiczno-typologiczne, Lublin 1995, p. 366-367.

Wąsowicz H., Litania do Wszystkich Świętych z najstarszego pontyfikatu biskupów krakowskich [in:] Peregrinatio ad veritatem. Studia ofiarowane profesor Aleksandrze Witkowskiej OSU z okazji 40-lecia pracy naukowej, ed. U. Borkowka, Cz. Deptuła, R. Knapiński, Z. Piłat, E. Wiśniowski, Lublin 2004, p. 557-570.

Weingartner J., Die Kunstdenkmäler Südtirols 2 - Bozen und Umgebung, Bozen-Innsbruck-Vienne 1991.

Wetesko L., Historyczne konteksty monarszych fundacji artystycznych $w$ Wielkopolsce do początku XIII wieku, Poznań 2009.

Wetter E., Bývalý hlavní oltářní retábl z dómu v Brandenburgu [in:] Karel IV. Císař z boži milostí. Kultura a umění za vlády Lucemburků 1310-1437, ed. J. Fajt, Praha 2006, p. 352-355.

Wiewióra M., Zespót klasztorny kanoników regularnych $w$ Trzemesznie $w$ świetle badań archeologiczno-architektonicznych, Torun 2000.

Wihoda M., Morava v době knižeci 906-1197, Praha 2010.

Wiśniowski E., Z problematyki kultu świętych [in:] Peregrinatio ad veritatem. Studia ofiarowane profesor Aleksandrze Witkowskiej OSU z okazji 40-lecia pracy naukowej, ed. U. Borkowka, Cz. Deptuła, R. Knapiński, Z. Piłat, E. Wiśniowski, Lublin 2004, p. 571-578.

Witkowska A., Titulus ecclesiae - Historia. Wezwania współczesnych kościołów katedralnych w Polsce, Warszawa 1999.

Wojciechowski T., Kościół katedralny w Krakowie, Kraków 1900.

Wyrozumski J., Dzieje Krakowa. Kraków do schyłku wieków średnich, Kraków 1992.

Žemlička J., ,,Politický kalendár” přemyslovských Čech, „Český časopis historický” 1991, 89, p. 31-47.

Žemlička J., Svatý Václav jako věčný kniže „Čechů” [in:] Svatý Václav, ed. P. Kubín, Praha 2010, p. 211-220. 